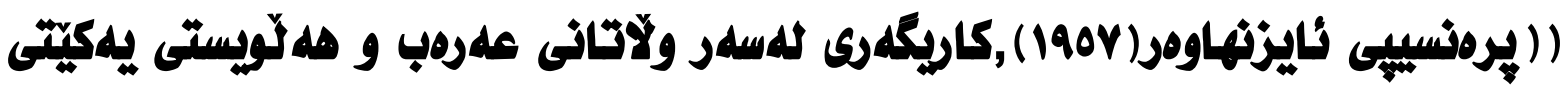

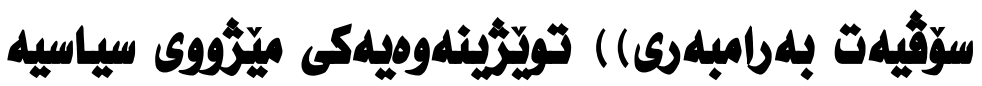

\section{هلريّم حسن احمد}

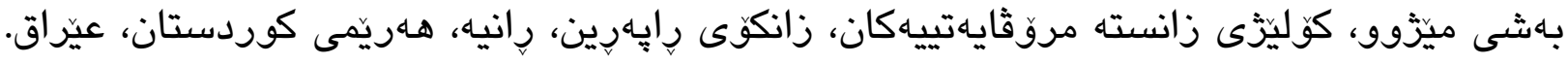
بيمهيل: haremranya58@uor.edu.krd

\section{يَّبِوار خالد مصطفى}

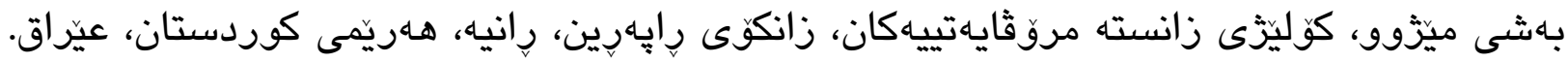
ئيمهيل: krebwar@uor.edu.krd

\section{ابراهيم على سليم}

بهشى ميّزوو، كوليّزى زانسته مروّثايهتييهكان، زانكوى رِإِرِين، رِانيه، هـريّمى كوردستان، عيّراق. ibrahimali@uor.edu.krd :يمهيل:

\section{هوخته: - بو}

پاش كوتايى هاتنى جهنكى دووهمى جيهانى، له ئاكامى كثانهوهى هيزّهانى بهريتانيا و فهرهنسا له بهشيك له

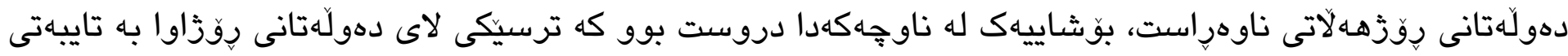

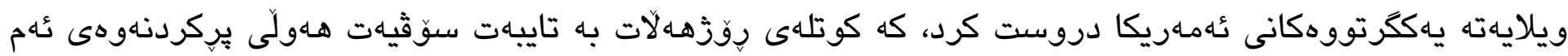

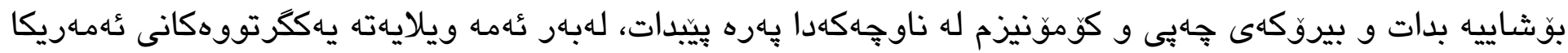

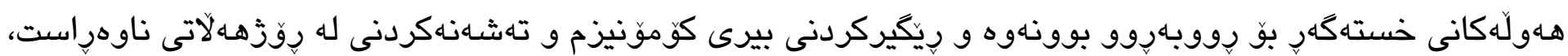




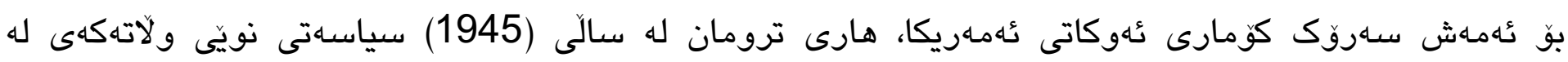

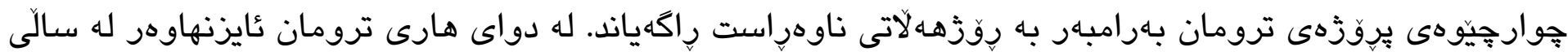

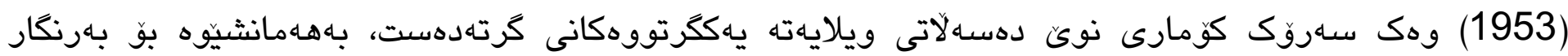

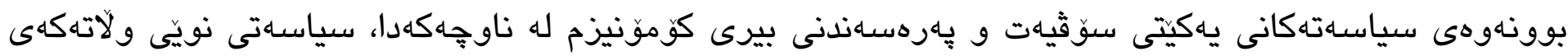

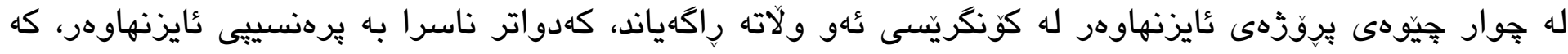

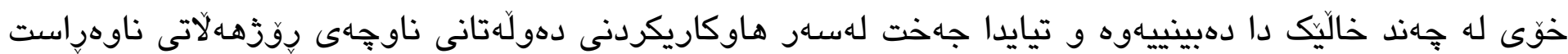
للهلايهنى ثابووريى و سـاربازى و رِيَّيركردن له بلاّوبوونهوهى بيرى شيوعيهت كردبوّوه.

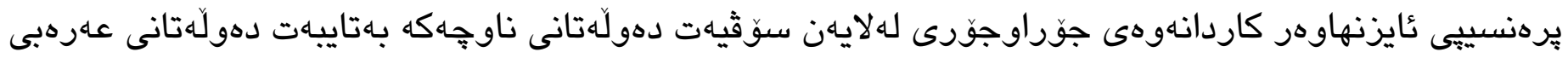

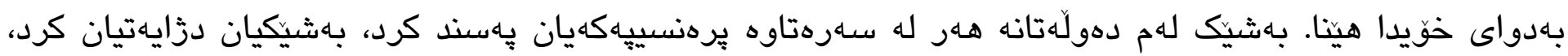

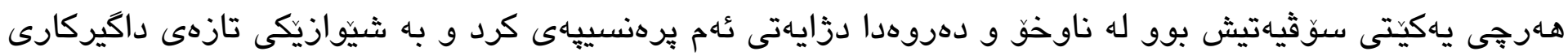

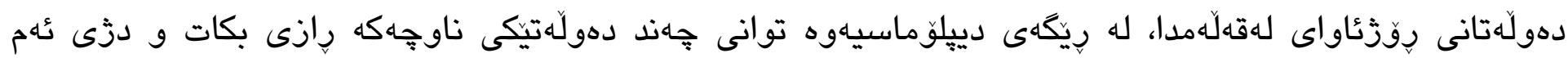

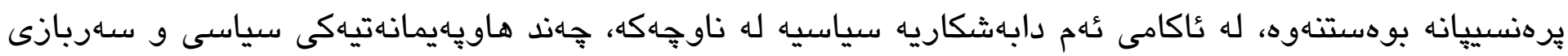
له نيّوان ئهم دهولَهتانهدا دروست بوو، بيرى ناسرى و بيرى قاهومى عهرهبى لهم ماوهيهدا سـهرى هـلَّا. تئهم بيروكهيه

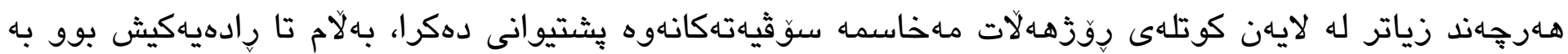
هوّى لاواز بوونى بيرى شوعيهت و نزيك بوو لهوهى بهرياهكهوتن دروست بييت له نيوان لايهنكرانى بيرى شيوعيهت

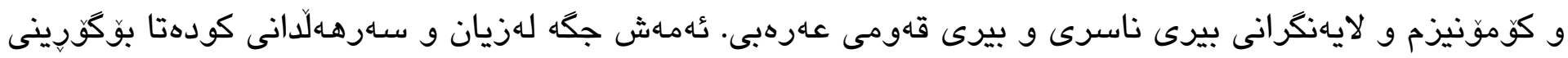

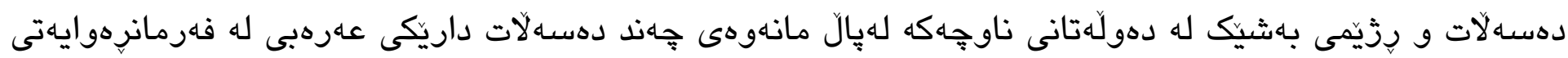

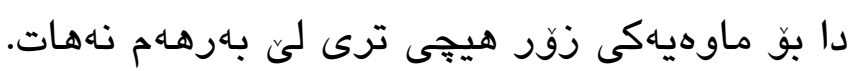

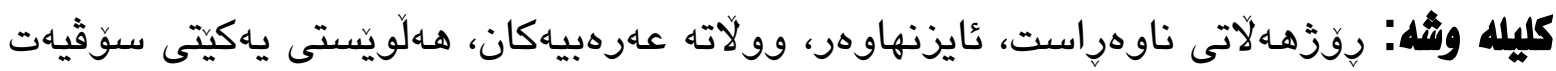




\section{SThing}

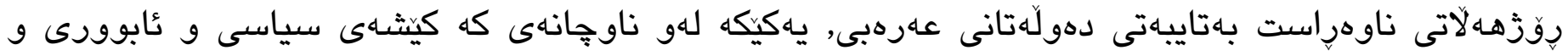

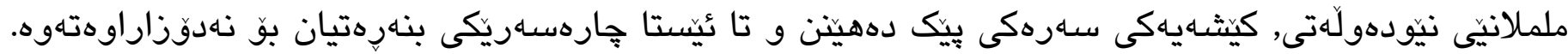

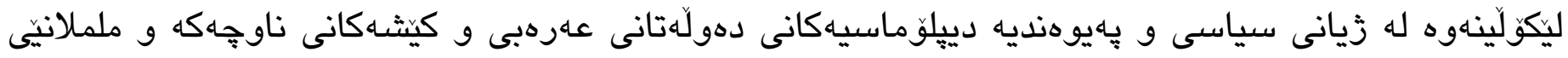

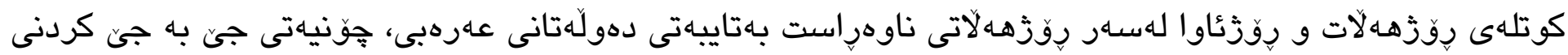
يرهنسييى ئايزنهاوهر و تيّروانينى سوّثيهت بهرامبهرى كرنكى و بايهخى تُهم تويّزينهوهيه دهردهخات.

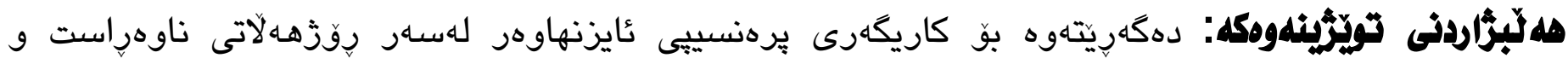

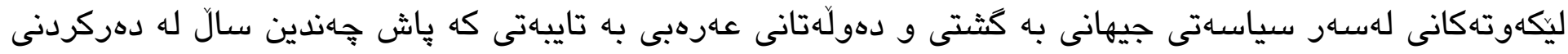

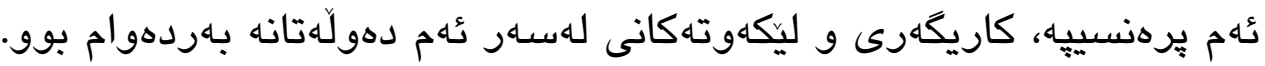

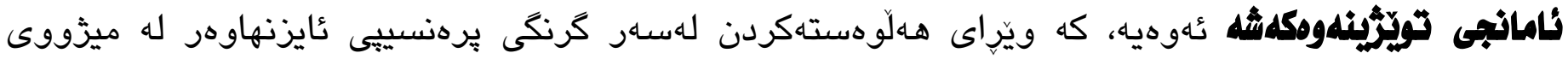
هاوجههرخى ناوجهاكهدا، دهيهوىَ ليكدانهوه بو بارودوخى سياسى و سـهبازى ماوهى كاركردنى ئهم يرهنسييه، و ئهو

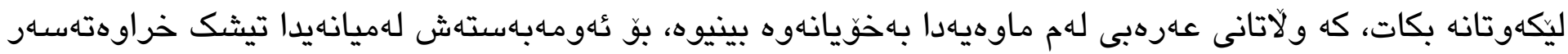

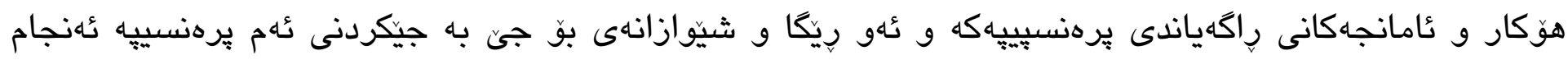
دراون، هـلوهستهشى لهسهر كاردانهوهكانى يهكيتى سوّيهت و تئه ليَكهوت و كاريخهريانه كردووه كه لهسهر بارودوخى سياسى و سـربازى ناوجهـكه هـيبووه. .

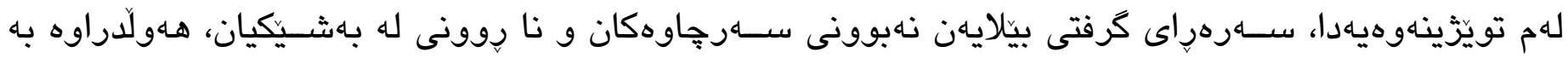

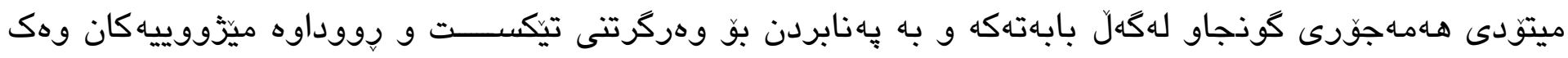

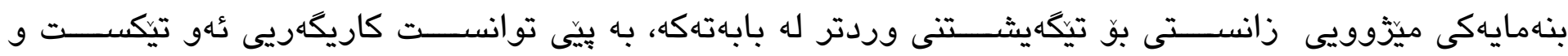

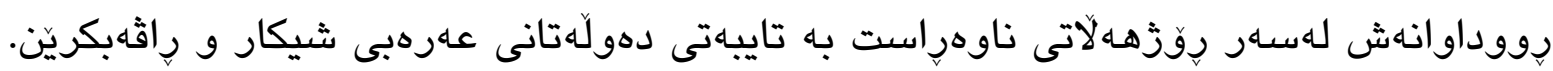

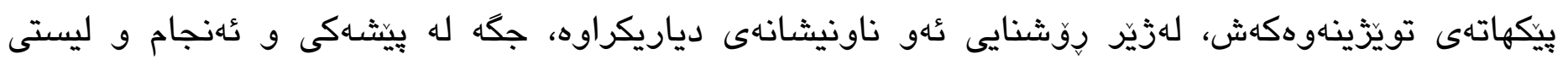

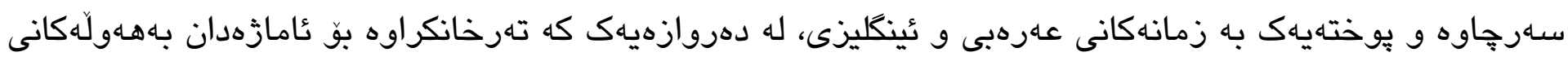

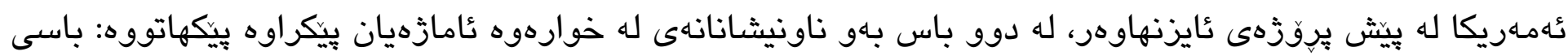

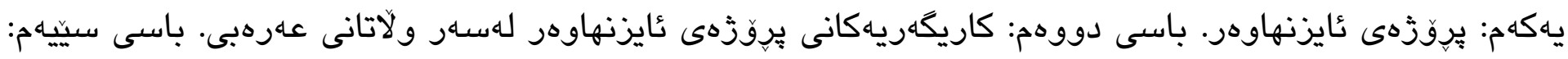
هـلويستى يهكيتى سوَثيهت بهرامبهر بِرهنسيبى ثايزنهاوهر. 


\section{sos}

ئهمريكا يه كيكه لهو دهولّهانهى كه توانى بهماوهيهكى كورت جيكاى سهركردايهتى سياسى نيّودولّهتى له جيهاندا

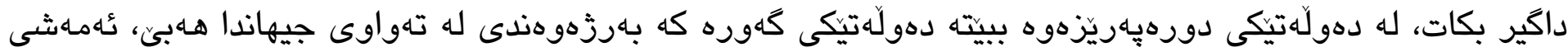

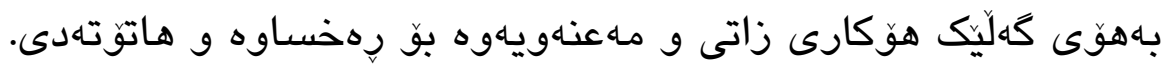

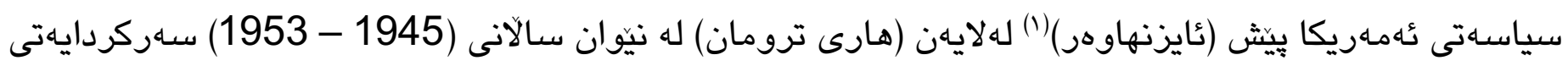

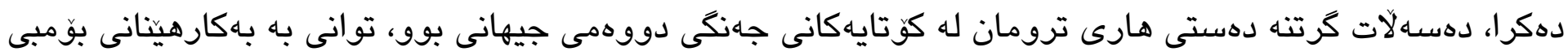

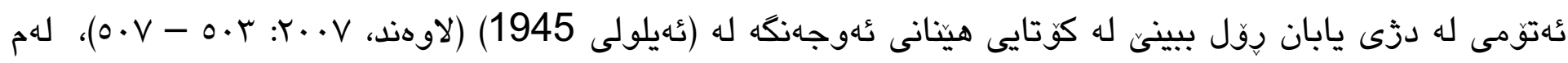

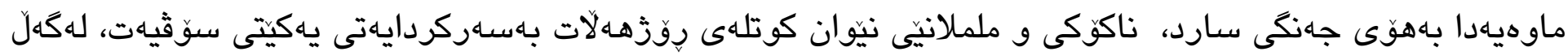

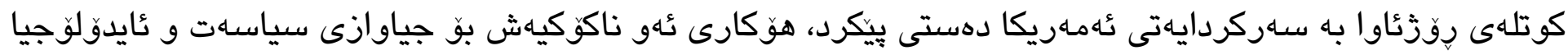

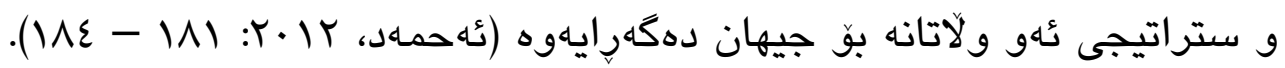

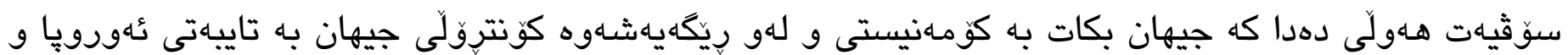

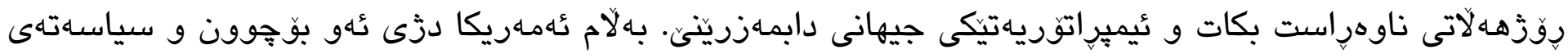

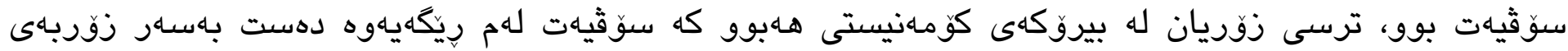

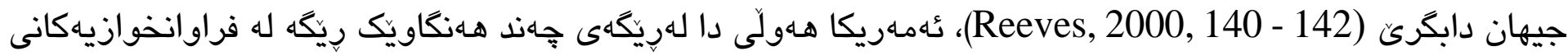

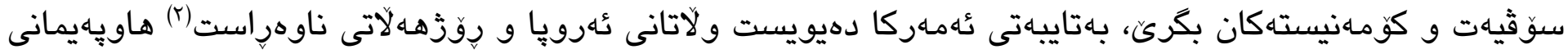

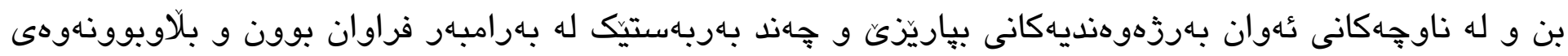

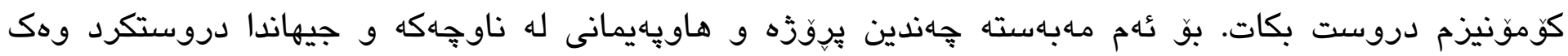

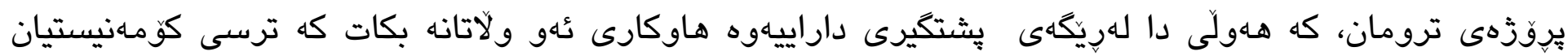

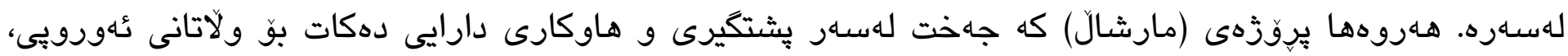

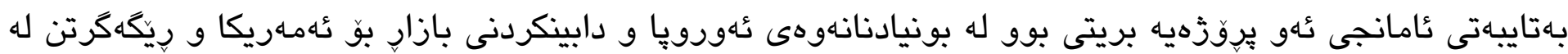

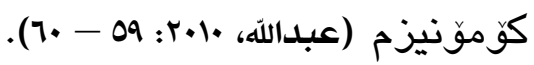

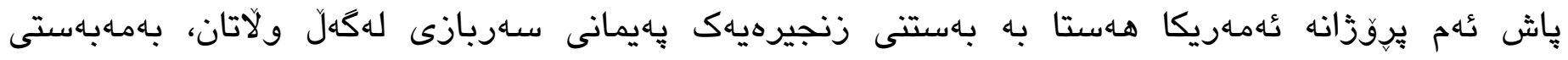

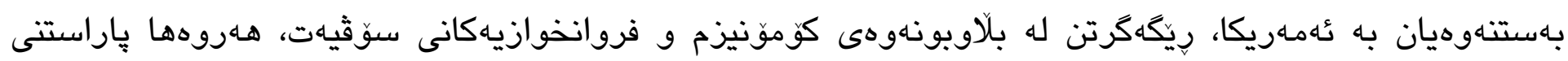

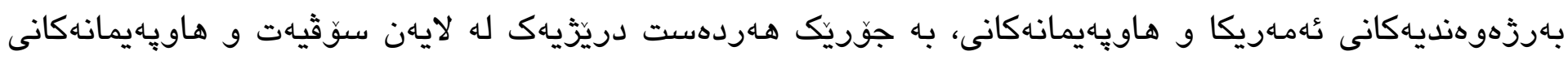

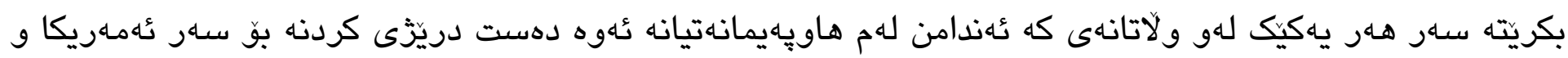

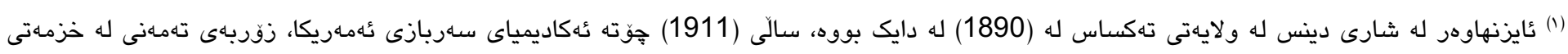

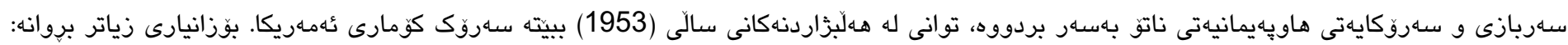
.(Reeves, 2000, 15)

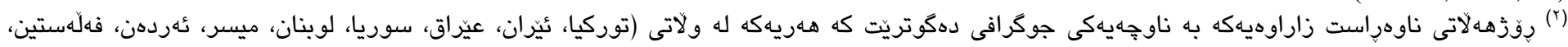

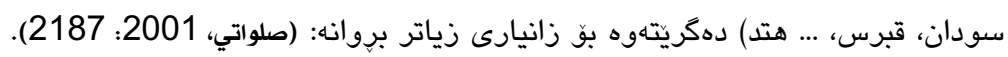


ولآتانى هاويهايمانى، له بهرامبهريش دا سوّثيهت بهههمان شيّوه جֶهند هاويهيمانيهكى دامهزراند، ئه بارودوخه

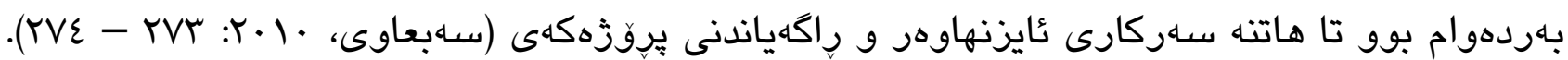

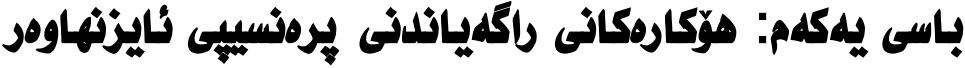

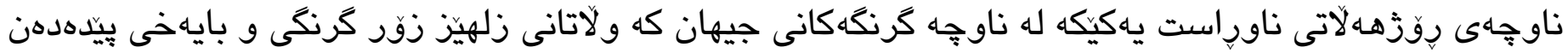

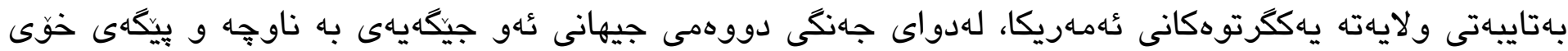

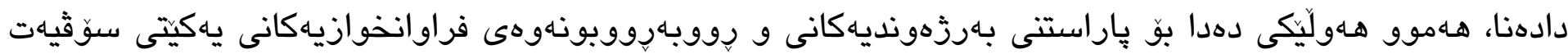

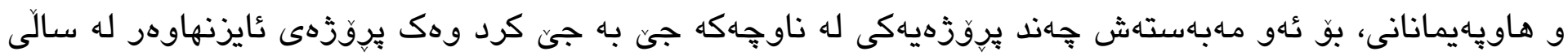

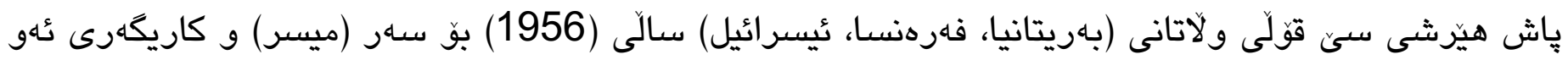

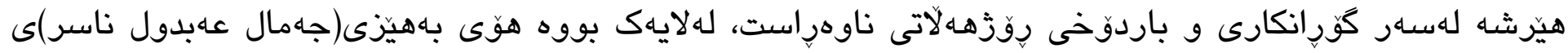

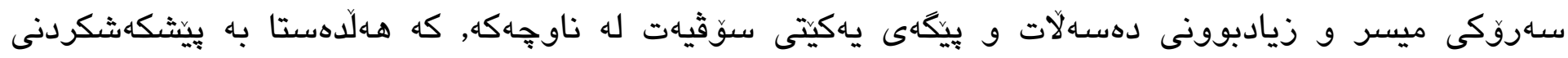

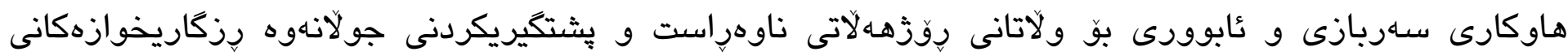

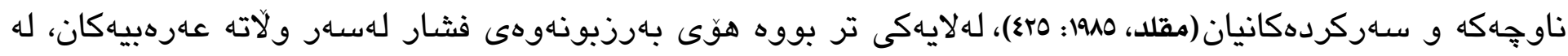

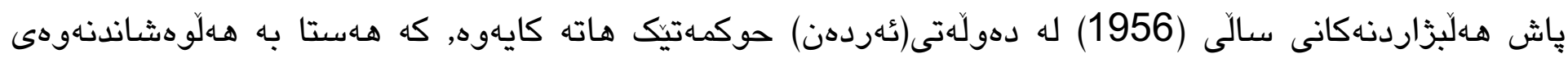

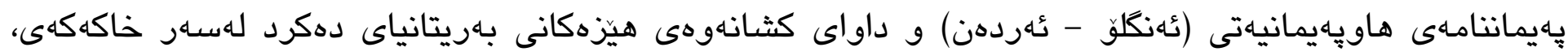

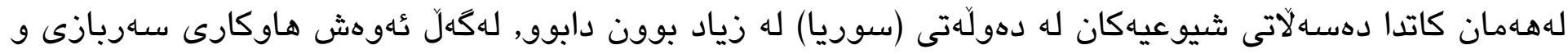

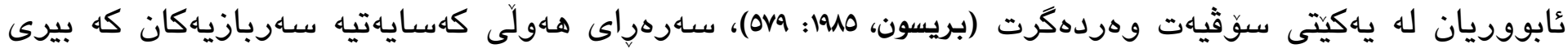

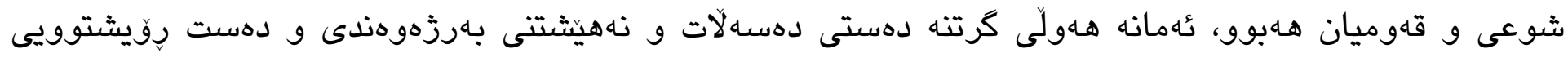

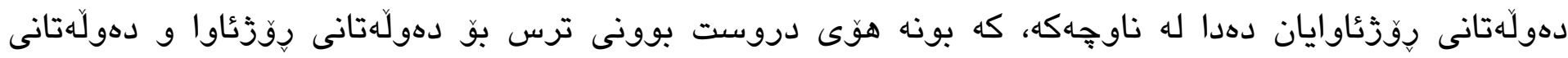

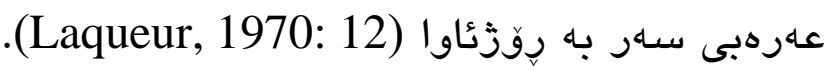

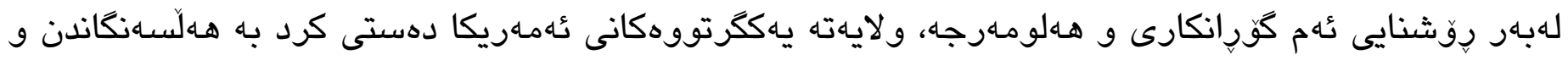

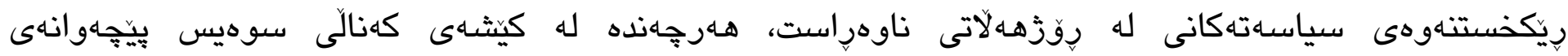

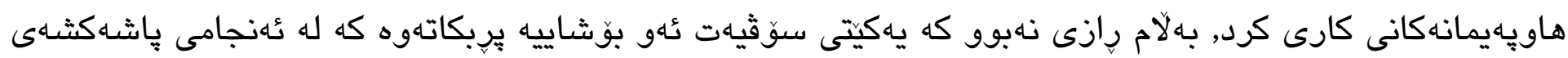

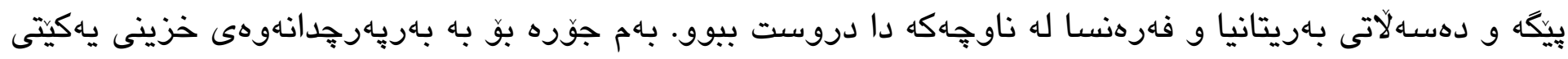

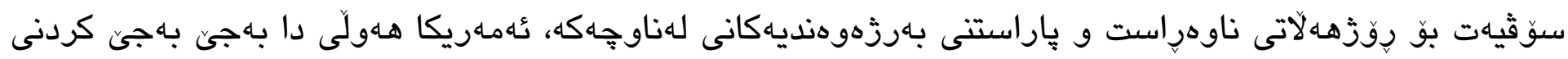

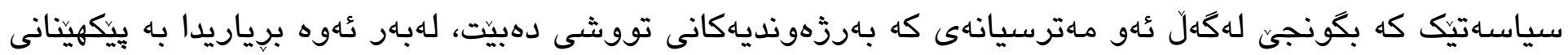




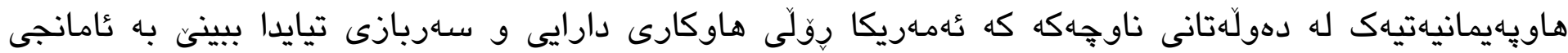

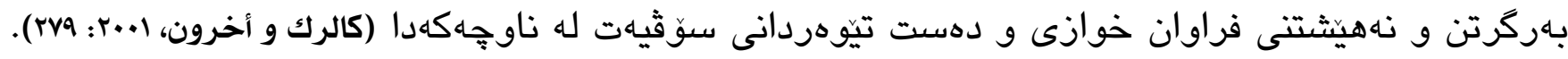
ولايهته يهككرتووهكانى عُهماريكا له (1956) نهخشهى خُوى لهزيّر ناوى (بهرقهراركردنى ئاشتى و كيّرانهوهى

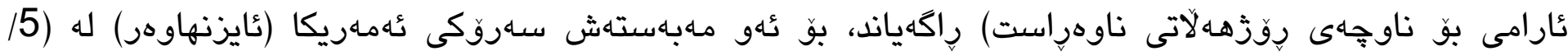

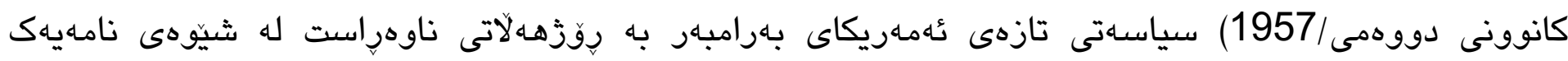

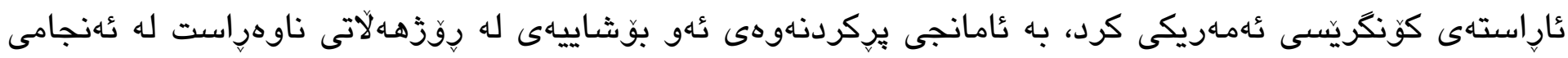

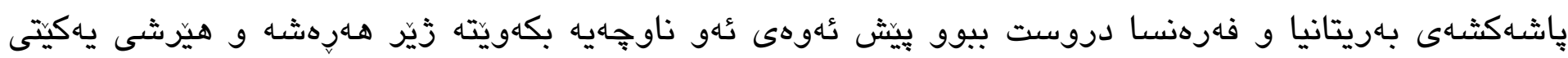

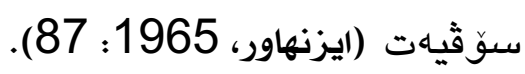

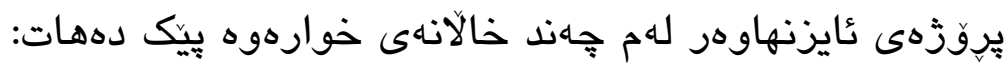
1 - بهكارهينانى هيزّ لهلايهن ئهمهريكا بوّ پِاريّزكارى كردن لهئاشتى ناوجهاكه و ساربهخو بوونى سياسى بو

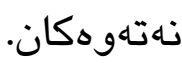

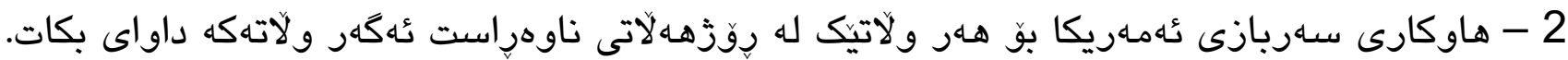

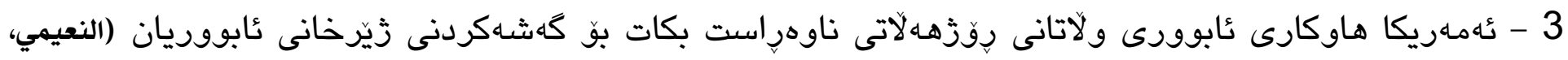
.(247:1970

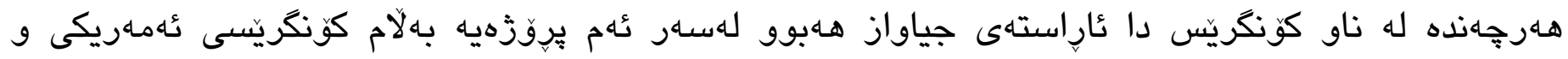

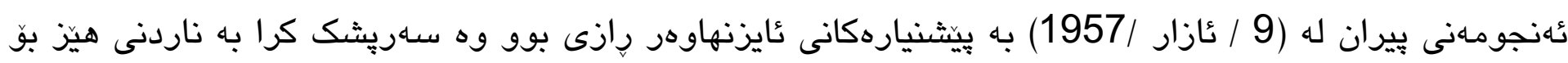

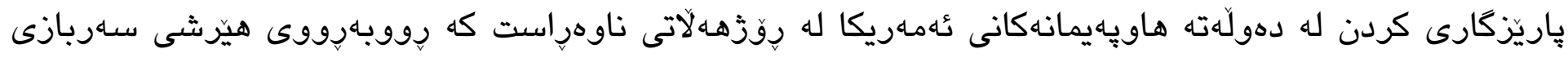

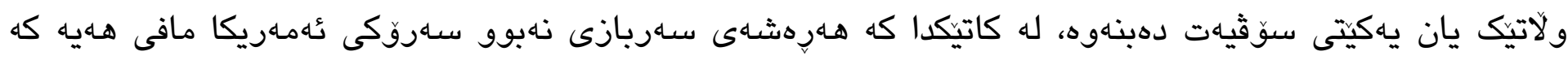

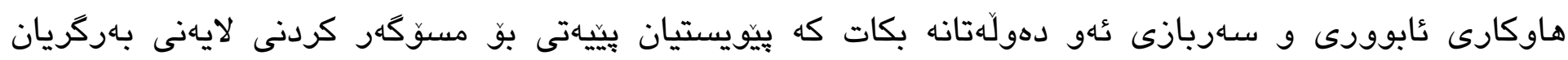
(البيضائي، 2003: 19 19).

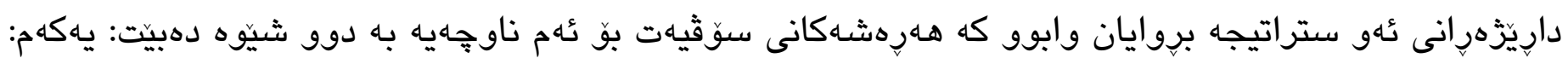

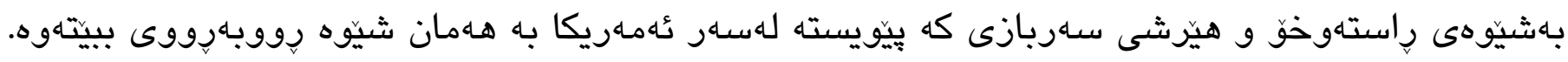

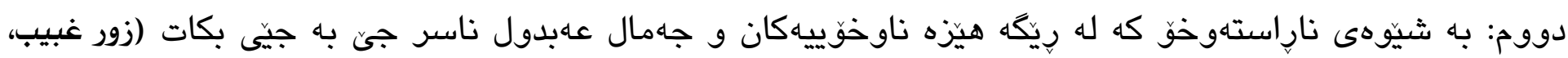
. $20-19: 1978$

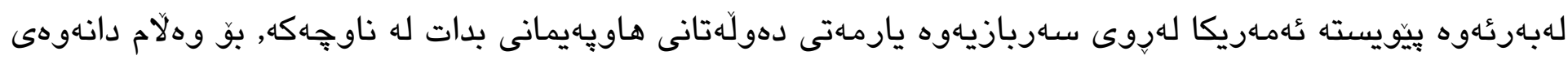

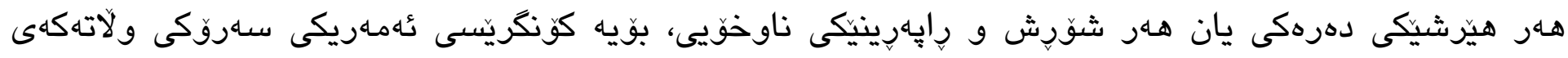




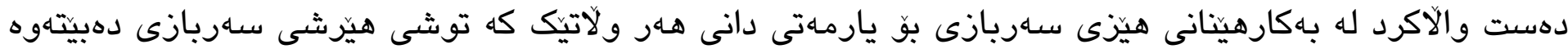

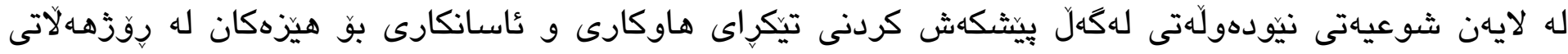

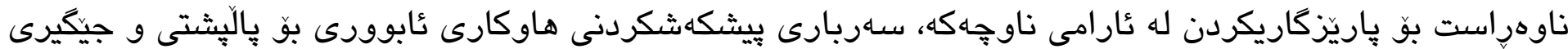

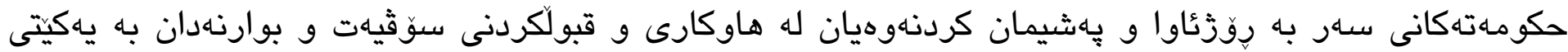

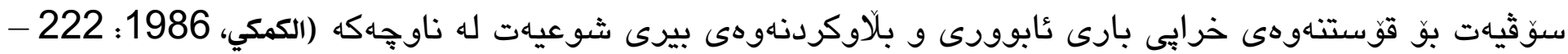
223)، بو عُهو مـاهباسته ئايزنهاوهر داواى لهكونكريسّ كرد مافى دابهشكردنى هاوكاريه ئابوورييهكان كه نزيكهى

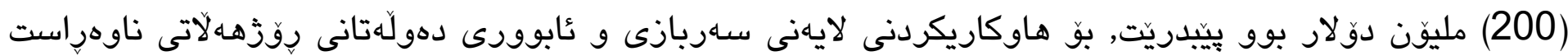
كه بييته بـربهاهت بوّ مـترسيهكانى سوّثيهت (رديف طالب، 2011: 252).

دهرئهنجامى ئهوه سـروّكى ئهمهريكا ئايزنهاوهر له سالّى (1957) نيزّدهى تايبهتى خوّى (جيمس ريشاردز)

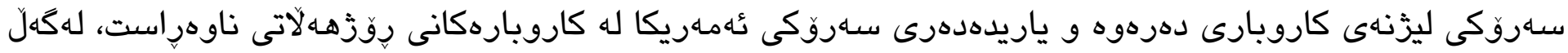

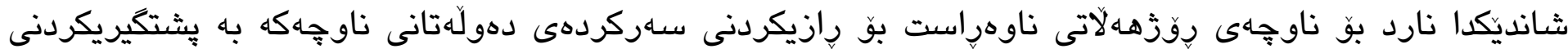
بوّجِونهانى عايزنهاوهر (منصور، 1996: 222).

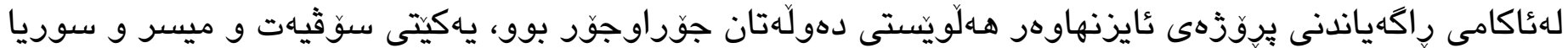

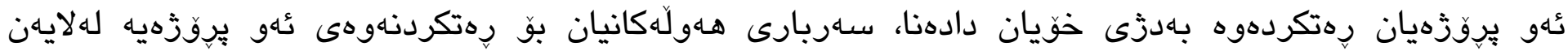

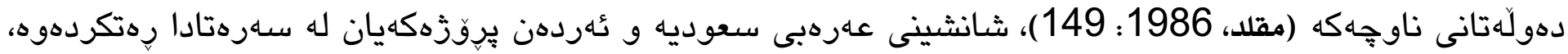

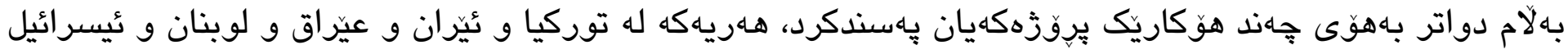

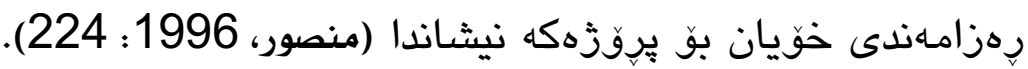

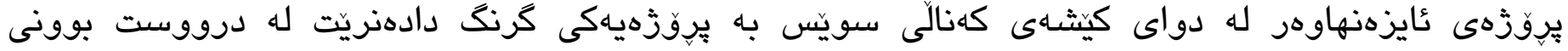

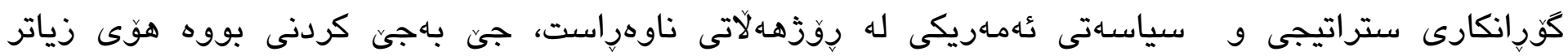

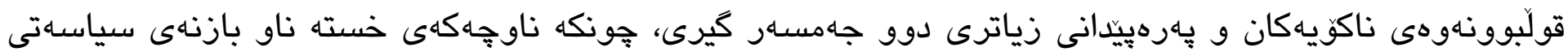

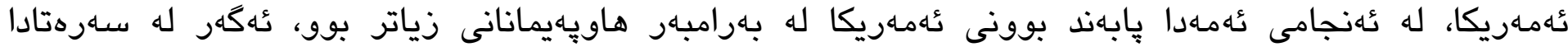

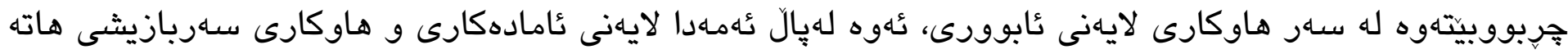

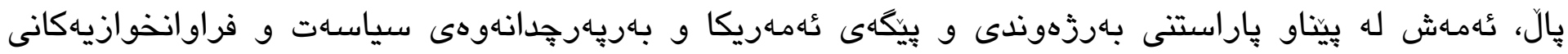

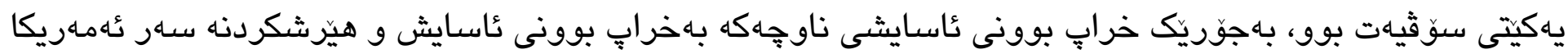

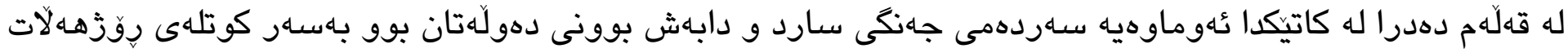
و رِخَّاوادا. 


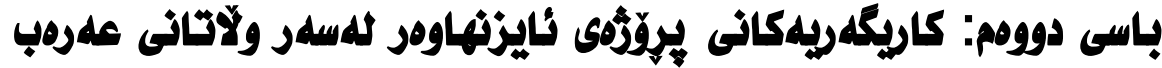

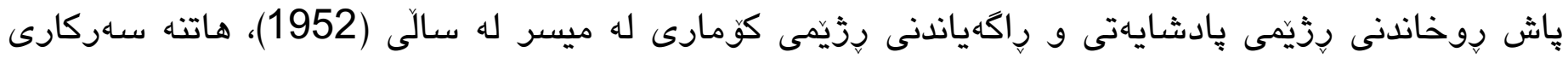
جهمال عهبدول ناسر وهك سـروَك كوّمار، له سالَى (1956), دهستيكرد به خوّمالِيكردنى نوكهندى سويّس و

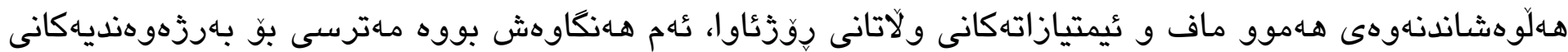
دهولّتانى بهريتانيا و فهرهنسا و رايانكاهياند كه هـنكاوهكانى سهروكى ميسر هـهرهـان بوّسهار جيهان، لهبهرئهوه بريارى وهثاندنى كورزى سـاربازيان له ميسردا (حسين العدول و أخرون، 1986؛ 375 - 387)، بهلاّم عـهمهريكا ترسى

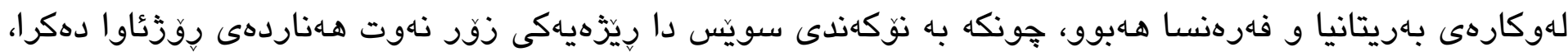

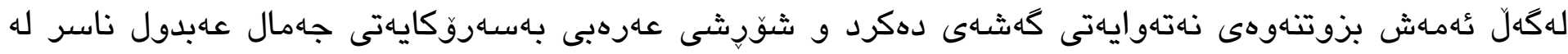
دزى ئهم ولآتانه دروست دهبوو (ذيب مليحة، 2012: 128)

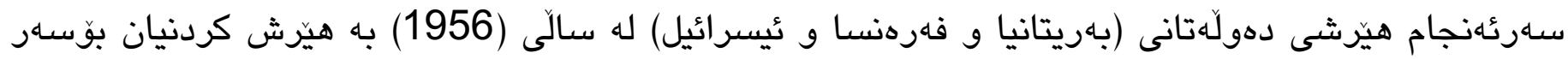

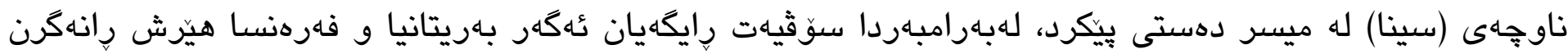

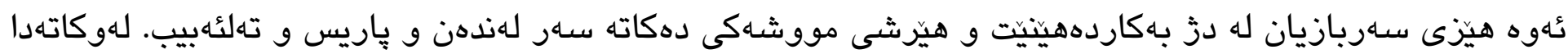

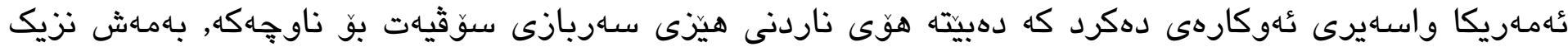

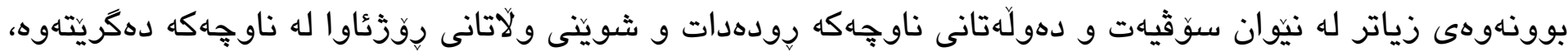

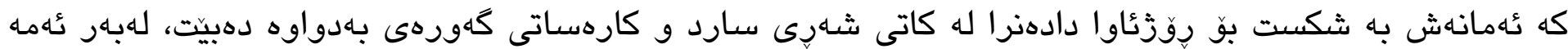

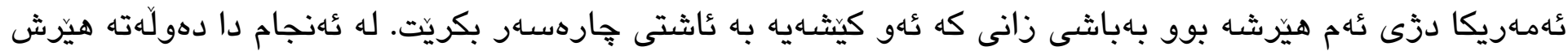
كهرهكان لهسالى (1956) بريارى كثـانهوهياندا لهو جهنكه دا ( Olson, 2016:50).

ياش كشانهوهى ئهو سيّ هيَزه و يشتكيرى سوّثيهت بوّ ميسر، بوه هوَى دهركهوتنى ناوبانكى جهمال عهبدول

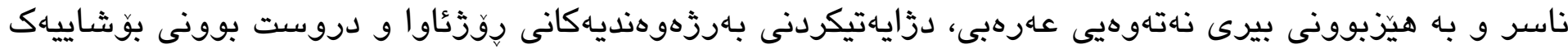

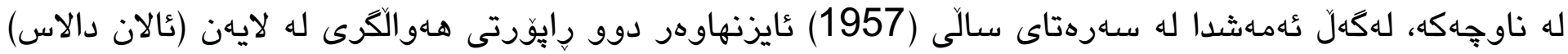

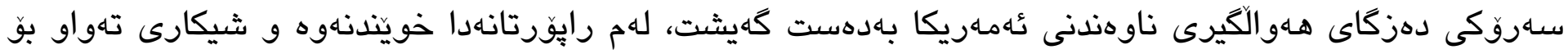

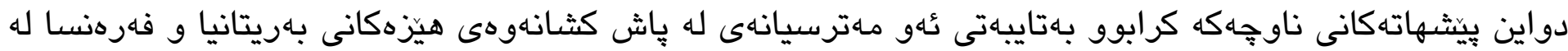

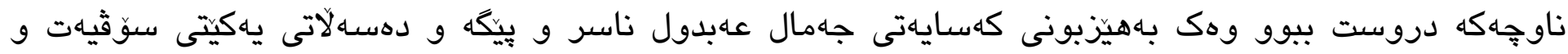
روودانى كودهتاى سـربازى له سوريا و بههيزّبوونى شوعيهكان لهم ولآتهدا، ئهم مـترسيانه واي له ئهمهريكا كرد

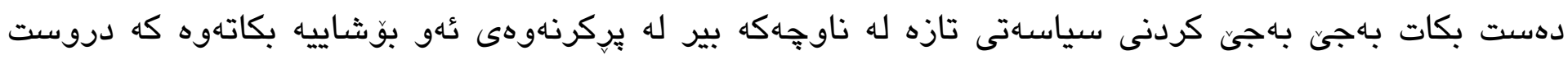

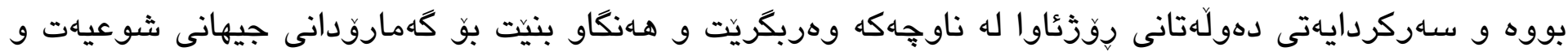
كُهاندنى هاوكارى عُهمه ريكى بوّ ناوجهـكه (الضيفي، 2011: 132 - 133). 


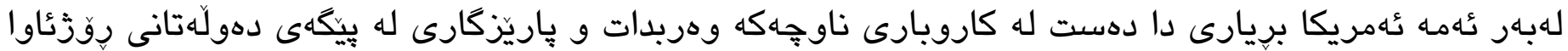

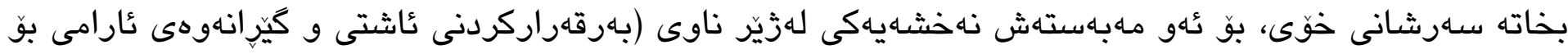

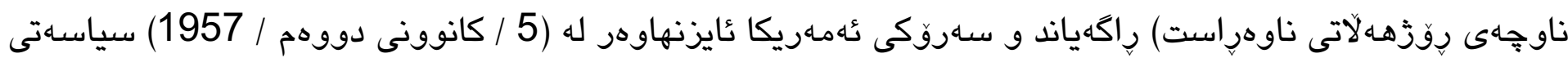

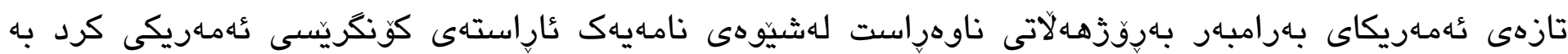

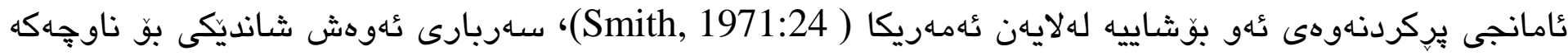

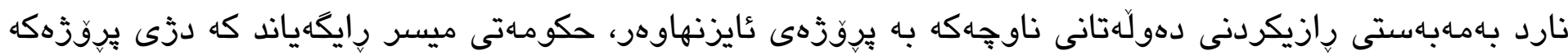

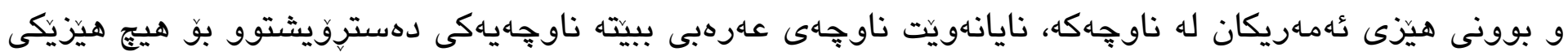

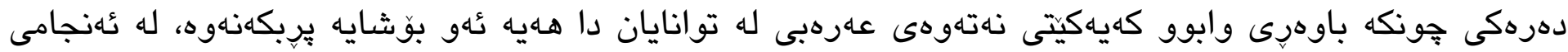

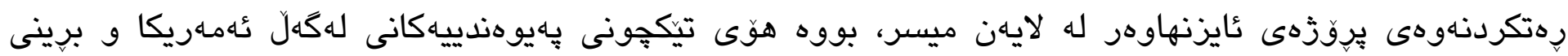
هاوكارى و كومهاكهانى ئهمهريكا بو حكوماهتى ميسر، ئهمهش بووه هوَى نزيك بوونهوهى سوّثيهت و ميسر و هاوكاريكردنى لله لايهنى دارايى و سهربازى (منصور، 1996: 224 - 226).

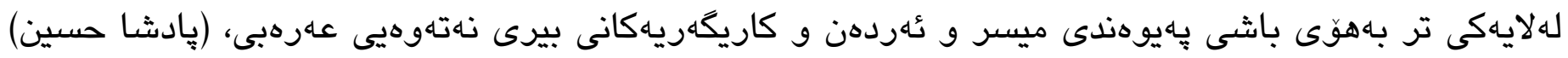

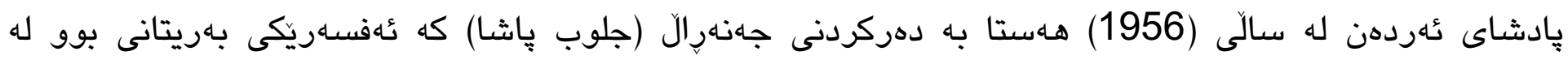

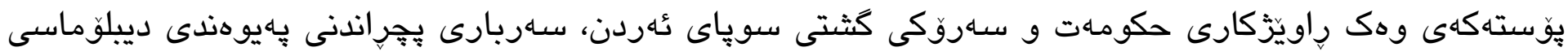

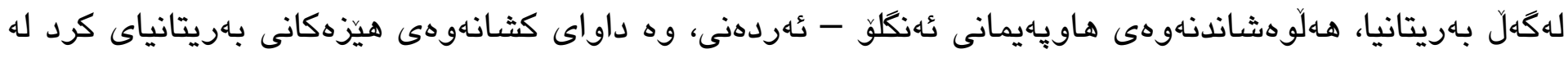
ئهردهن (بريسون، 1985: 579 - 580)، وه حكوماهتيكى بهاهـوركايهتى (سليمان نابلس)(')، له نهتهوهخوازهكان دروست

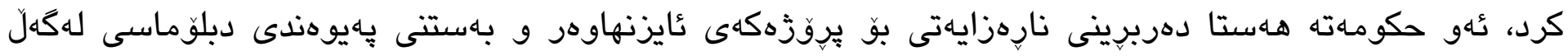

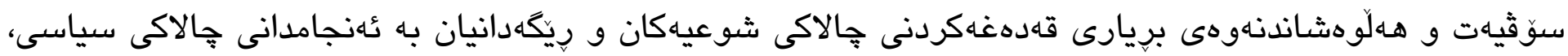

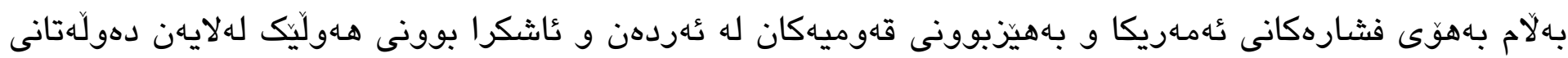
ميسر و سوريا بوّ روخاندنى حكومـتهكهى، ترسى لهلاى مـليك حسين دروست كرد كه ئهم كارانه بييته هوّى له دهست دانى يِّكَّكهى (نعمان الدوري، 2003: 63).

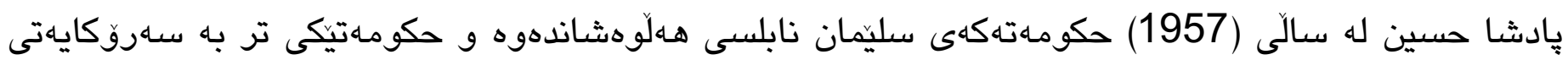

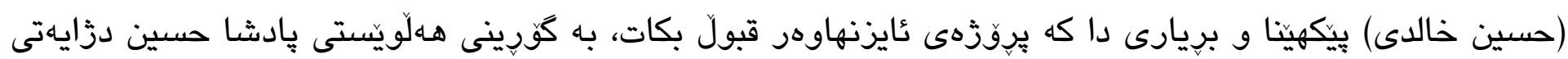

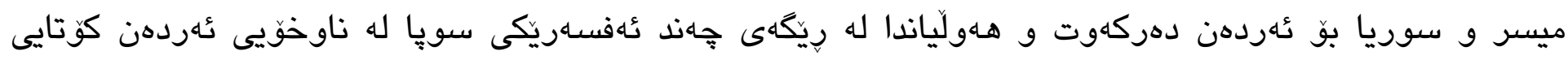

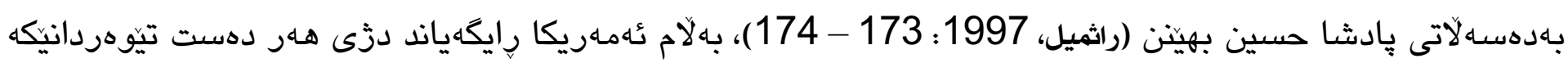

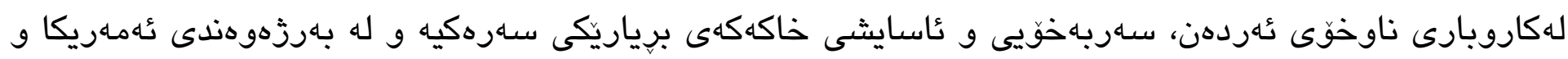

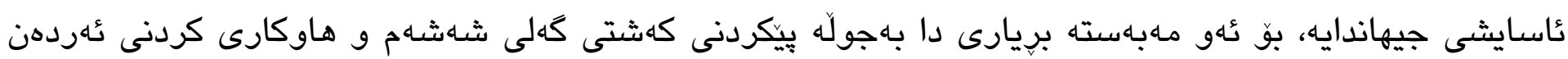

(') كهاياهتيهكى سياسى ئهردنيه له سالى (· (197) له شارى (سلط) له ئهردهن له دايك بووه، زانكوى ئهماريكى لهبهيروت تهواو كردووه بو زانيارى زياتر برِوانه: (الكيالي، 1974: 316) 
لهروىى داراييهوه به برِى ناردنى (10) مليوّن دولار و برِياريدا ئهم هاوكاريه دارييه سالآنه بـرددوام بيت. سـارئهنجام

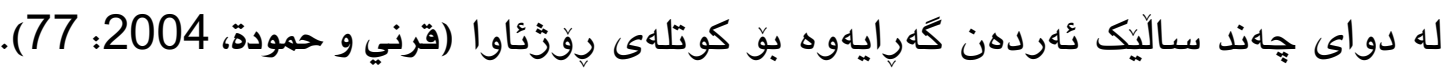

باش بوونى يهيوهنديهكانى سوريا و سوّثيهت و بهستنى هاوياهيمانى سـهربازى و ئابوورى له سالخى (1957)،

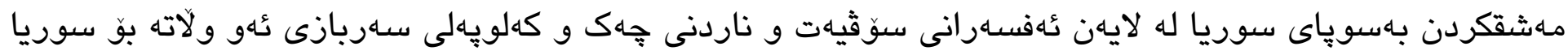

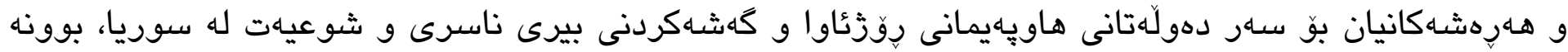

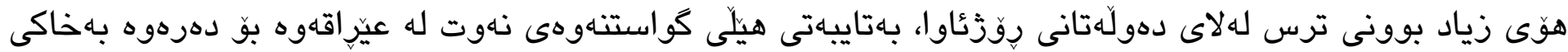
سوريادا تيّيهردهبوو ئهمهش به واتاى كونتِوَلكردنى ئهو هيلّه لهلايهن سوَثيهتهوه (السبعاوي، 2013: 221 - 224)،

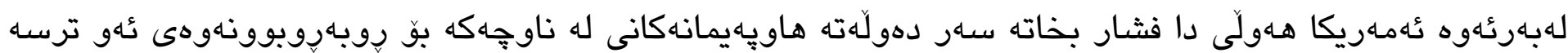

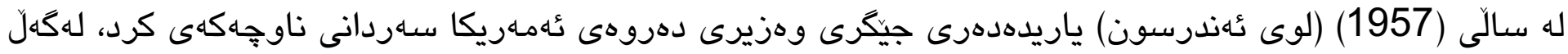

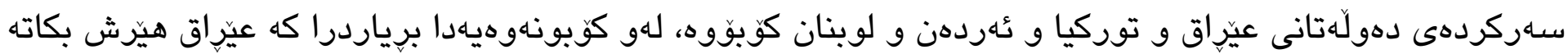

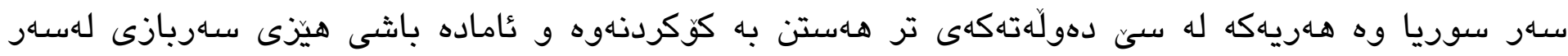

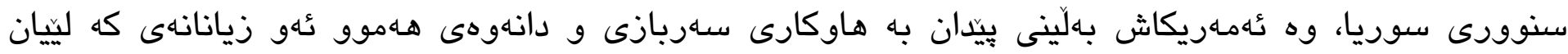

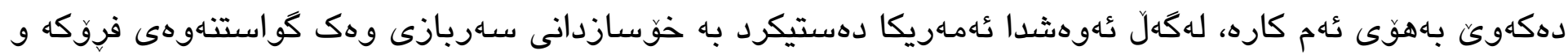

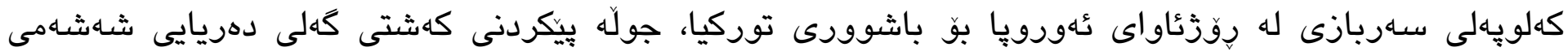

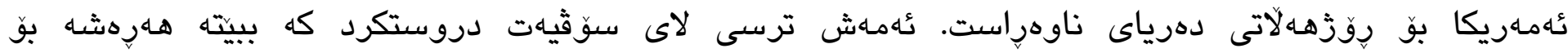

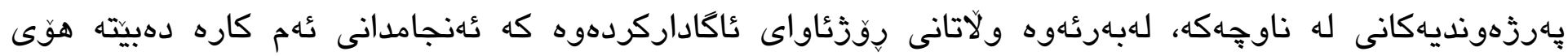
بهكارهينانى هيّزى سـهربازى و وهلاّم دانهوهى سوّثيهت (عبدالعال، 2003: 218 - 219).

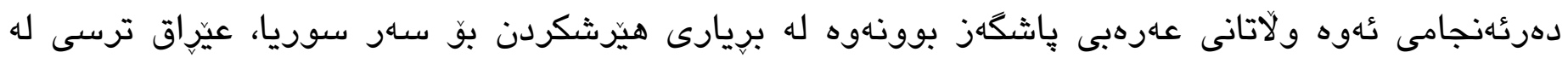

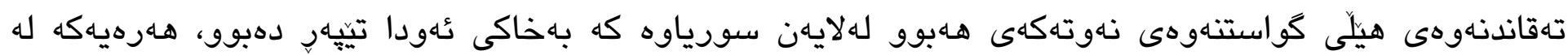

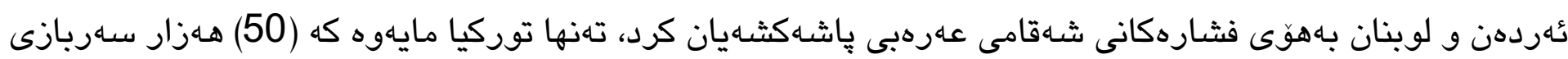

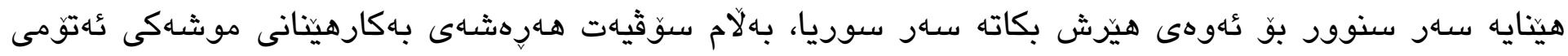

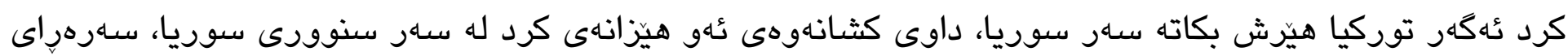
ئهوه دهستيكرد بهجوله يِيكردنى كهشتيه جهنكيهكانى بو ميناى لازقيه، سهربارى ئهنجامدانى نمايشيكى دهرياى له

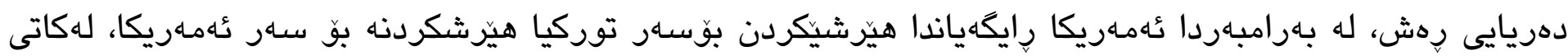
هيّرشى سوّثيهت بوّسـر توركيا ئهو به هيَرش كردنه سـرخاكى سوَثيهت وهلامى دهداتهوه. بوّيه هـهردوو لا

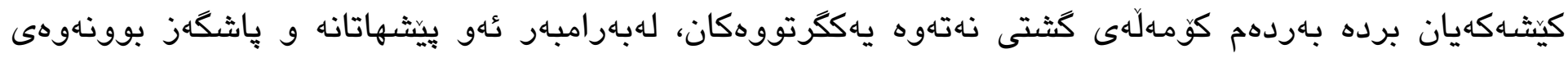

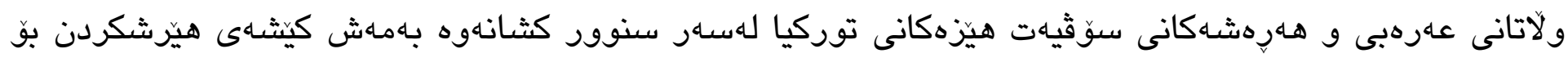
سهر سوريا كوتايهات (بن الصادق، 2017: 97 - 100). 


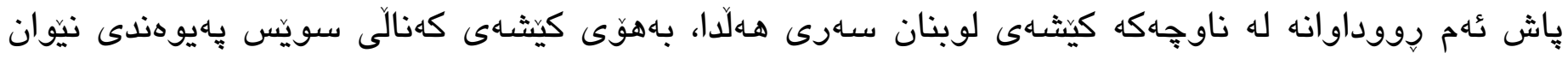

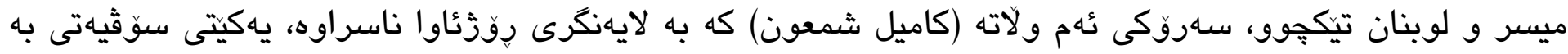

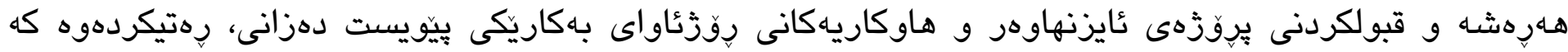

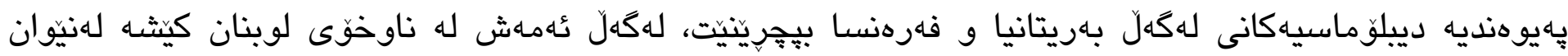

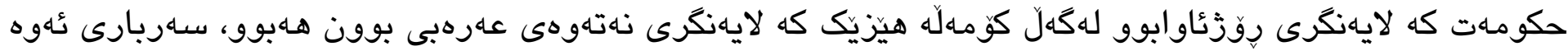

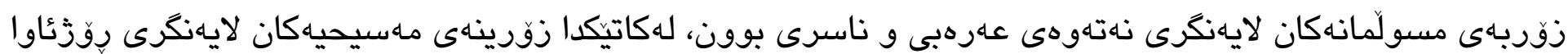

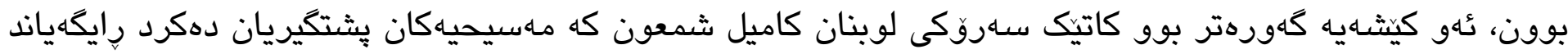

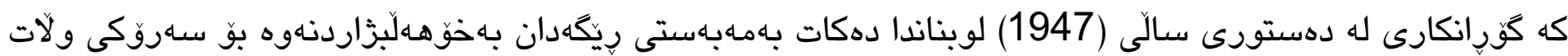

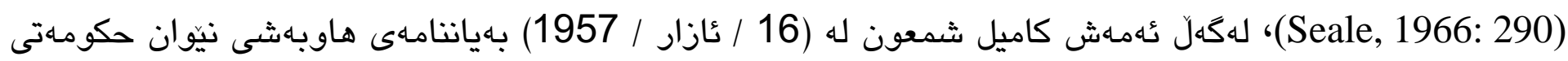

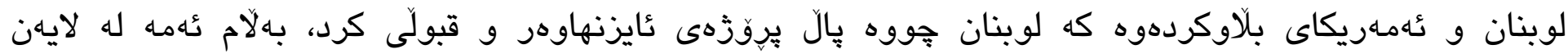
مسولّمانهكان رهتكرايهوه، سـربارى تئمـه ميسر و سورياش بريارياندا به شيّوهى سياسى و سـربازى هاوكارى

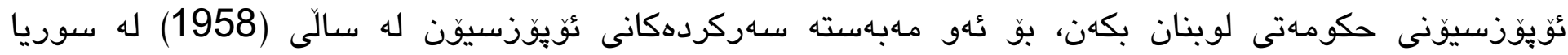

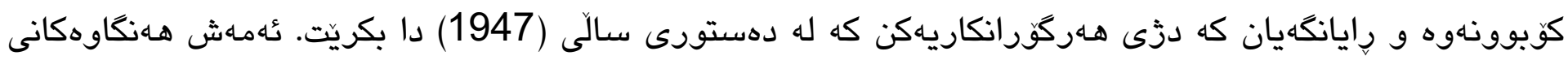

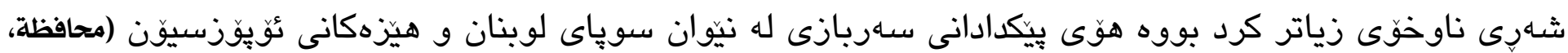

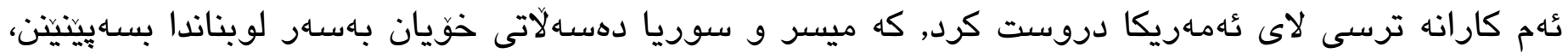

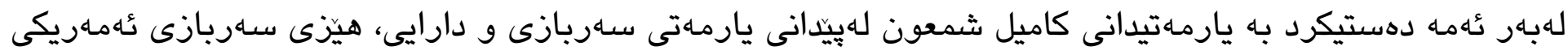

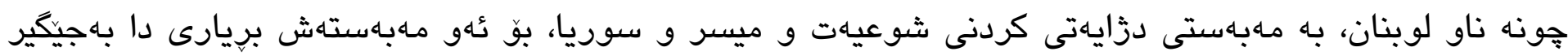

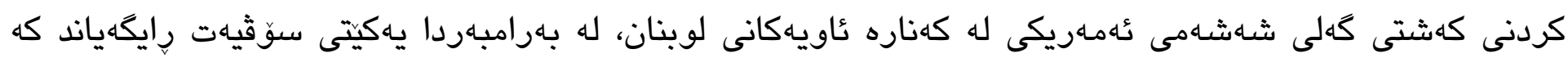
ئهم كارهى ئهمهريكا داكيركارى ئاشكراى لبنانه و داواى كثانهوهى هيزّهكانى ئهمهريكاى كرد ئهركهر نا بههـامان

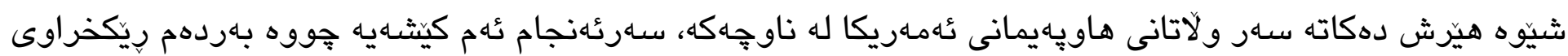
نهتهوه يـككرتووهكان و برياريدا كه هيَزهكانى ئهمهريكا له لوبنان بكيثينيهوه، له (25 / تثرينى يهكهم / 1958)

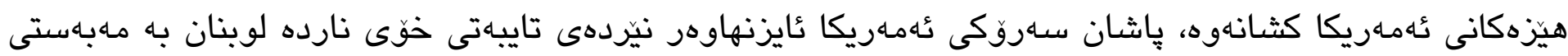
جارهسـاركردنيكى مامناوهندى له نيّوان لايهنه نهيارهكان، بوّئهو مـهبهته دهستكرا به كَتوكُوكردن له نيّوان (كاميل

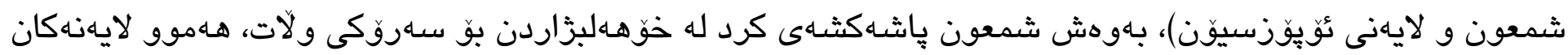

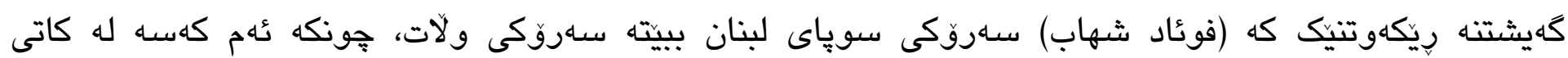

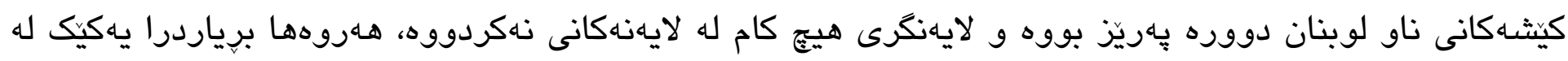

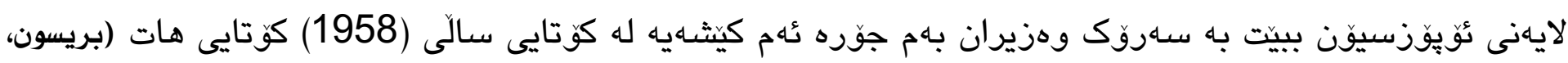




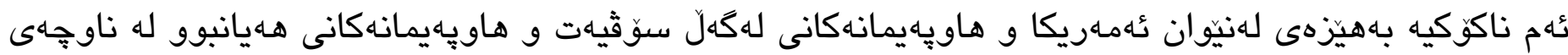
رِوزهـلآتى ناوهراست وه ئهو بوّشاييهى كه له ناوجهـكها دروست بيوو له ياش كثانهوهى بهريتانيا و فهرهنسا،

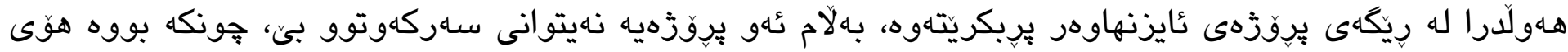

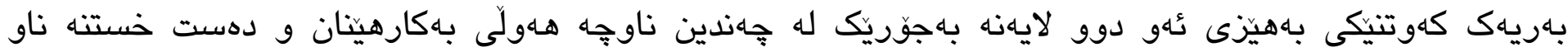

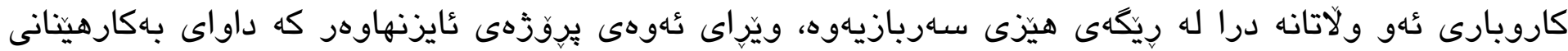
هيّزى سـهربازى دهكرد بو ياراستنى بـهزدونديهكانى رِوزئاوا و له ناوبردنى شوعيهت و بيرى ناسرى و قهومى

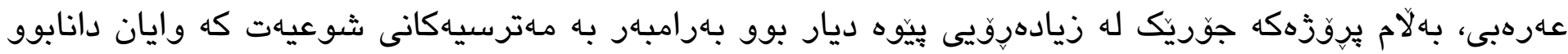

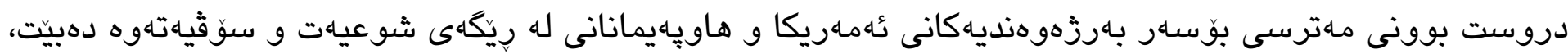
له كاتيكدا له ناوجهكهدا جههندين رهوت و تهيارى ترى وهك ناسرى و نهتهوهخوازى و بهعسيزم سهرى هـلَّابوو،

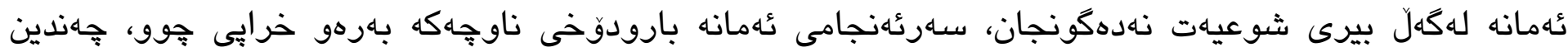

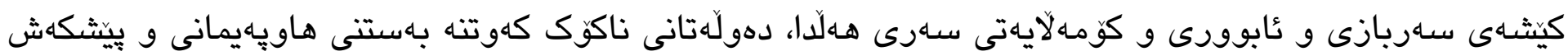

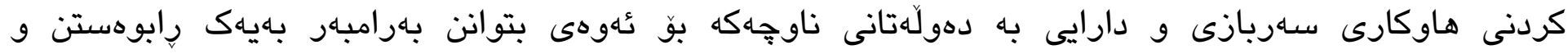

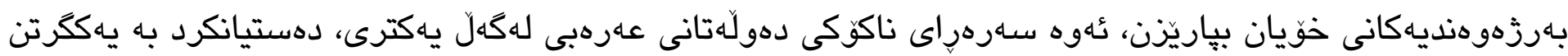

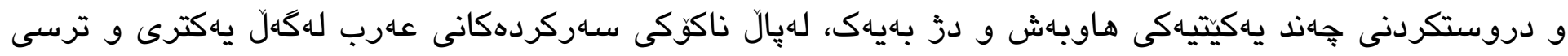

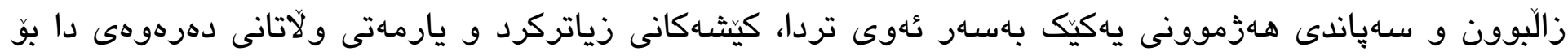

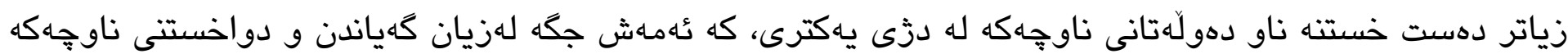

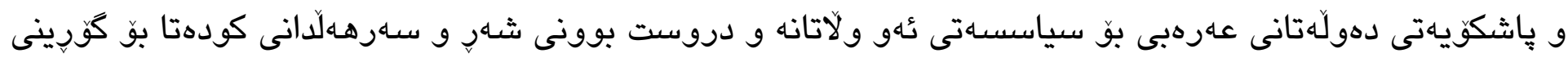

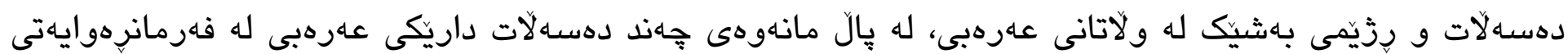

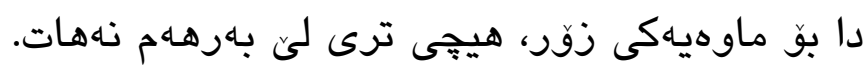

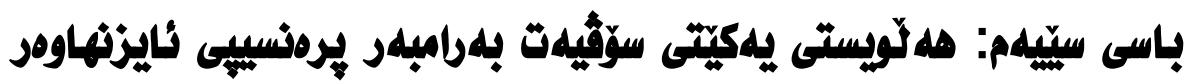

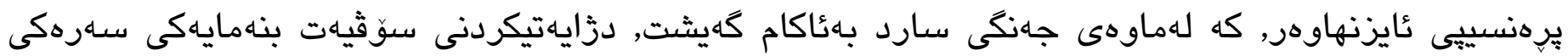

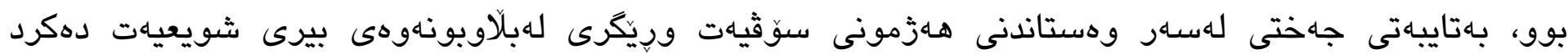

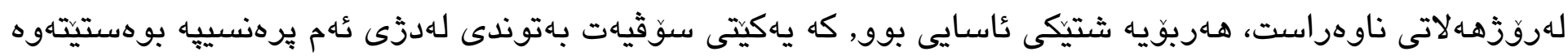

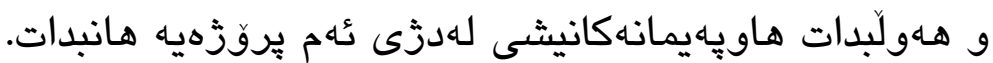

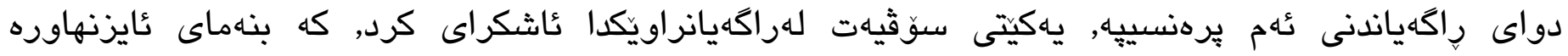
زيندوكردنهوهى داكيركارى كونه و كاريكى دوزمنكارنهيه، رهخنهى تُهوهى له ئهريكا كرت, كه پِهناى بردووه

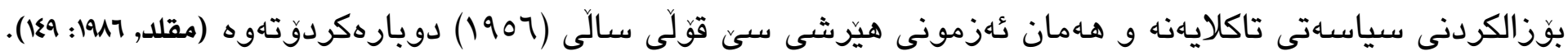




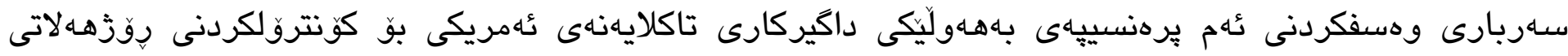

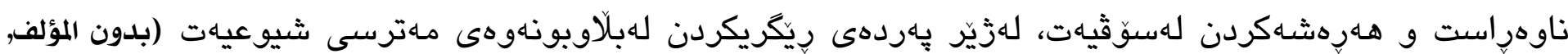

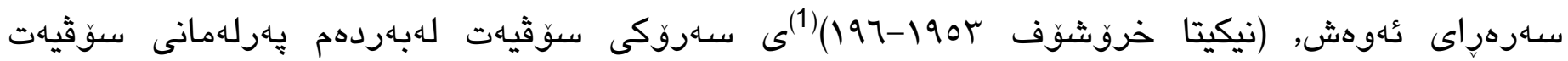

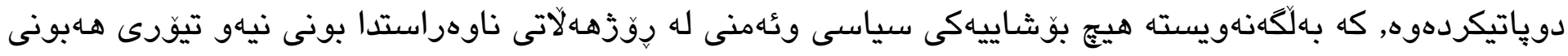

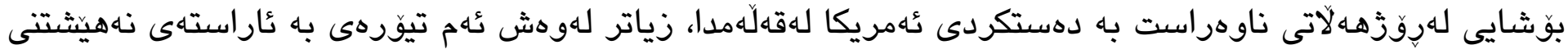

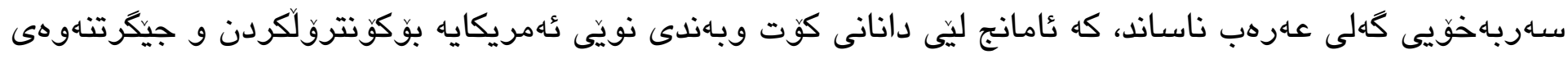
داكيركارى بـريتانيا وفهرهنسيهكان لهناوجه كهدا (بلدون المؤلف, 1977: 14)، تهنانهت يهكيتى سوّقيهت سـردانى نيّردراوى

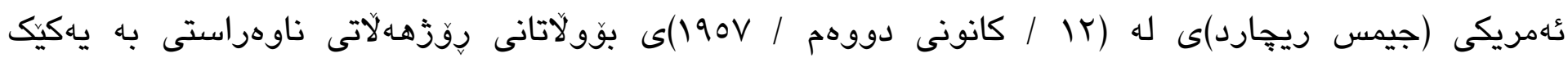
لههـاهولَكانى ئهمريكا ئهزّماركرد بوّكونتروّلكردنى ئهم ناوجهه ستراتيجيه (مخيبر، 2005: 135).

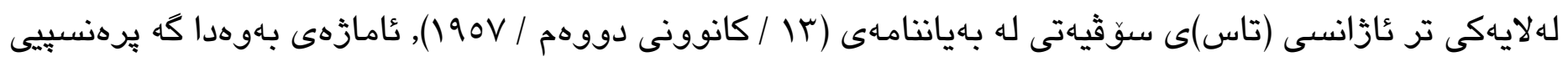

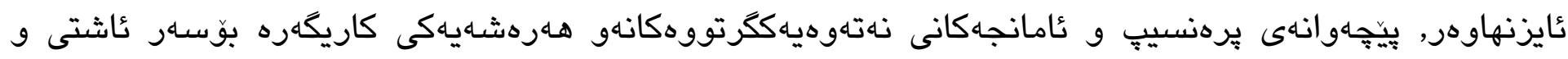

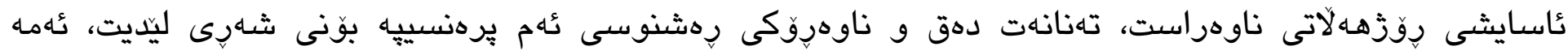

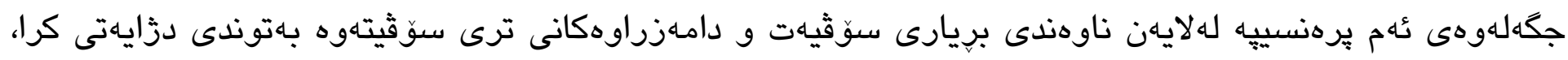

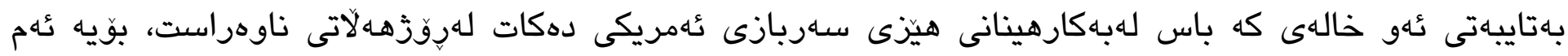

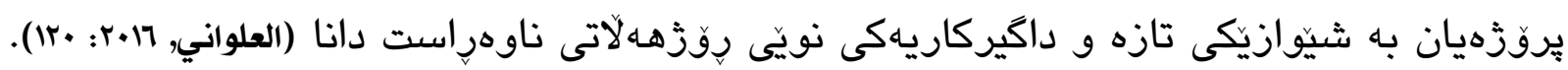

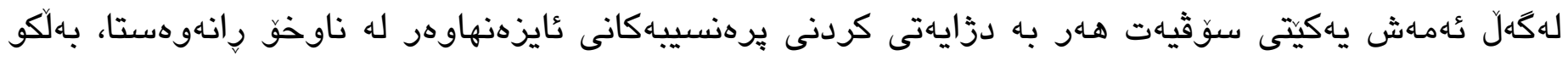

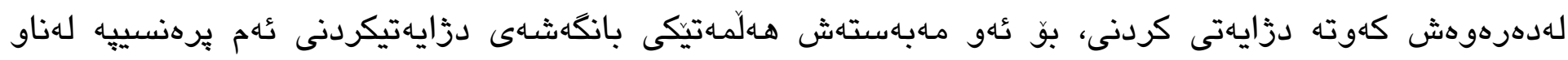

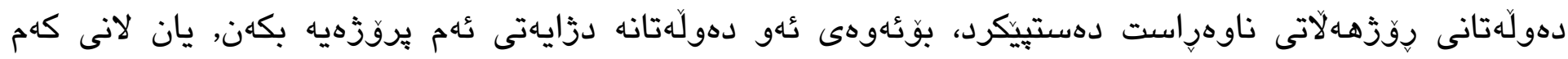

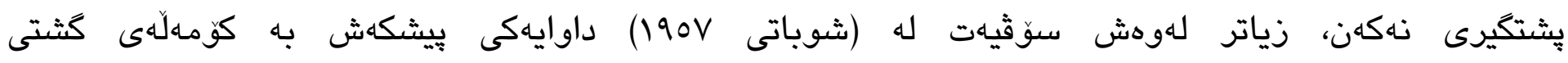

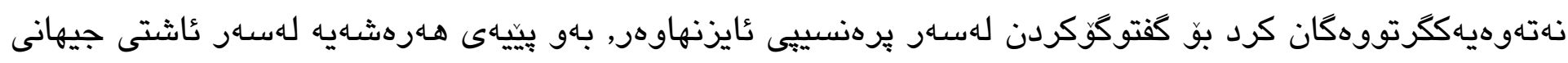

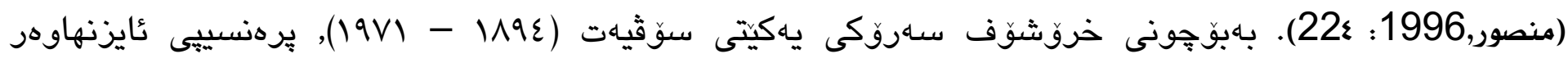
دهرخستنى رووىى راستهقينهى ديبلوماسيهتى ئيزديواجى ئهريكايه كه مومارهسهى دهكات لهروزّهـلاتى ناوهراست،

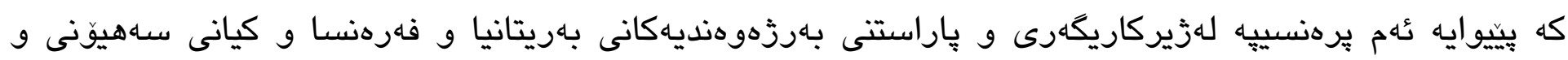
فريودانى رِاى كُشتى عهرهبى دهركراوه، بوّيه بوّجونى وابوو, كه يِّويسته ئهم يرهنسيِيه لهكاربخريت و كارى

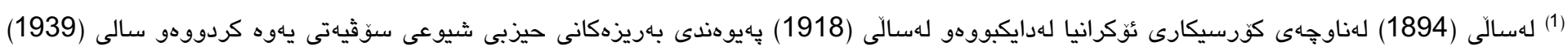

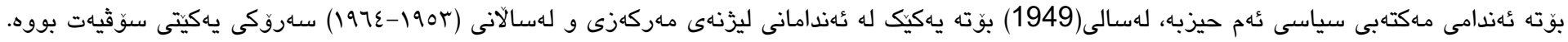

بوّزانيارى زياتر بروانه: (مجموعة المؤلفين, 1992: 79 - 83). 


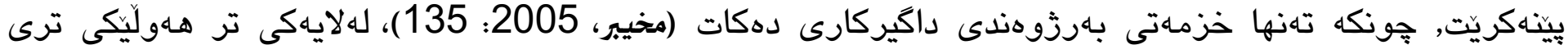

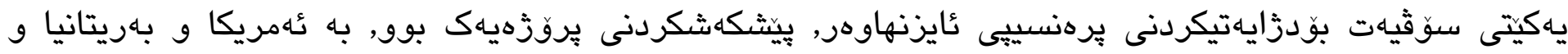

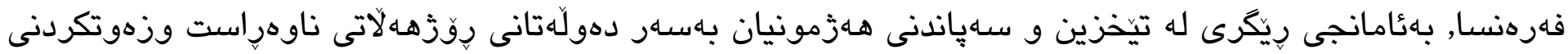

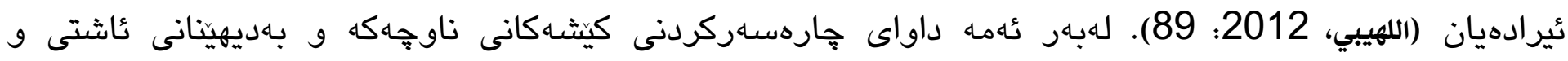

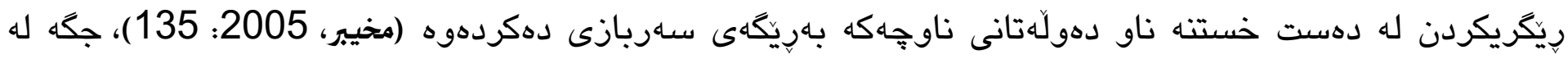

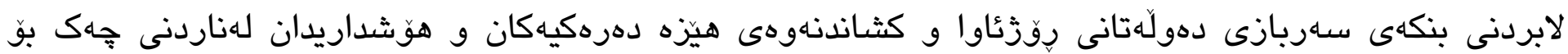
ناوجهـكه (منصور, 1996 : 223) .

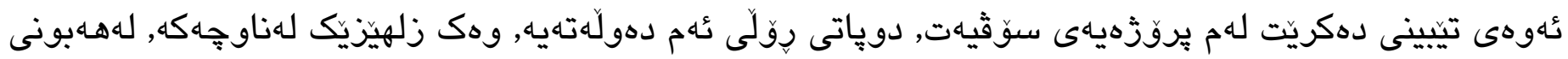

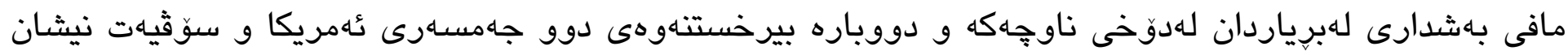

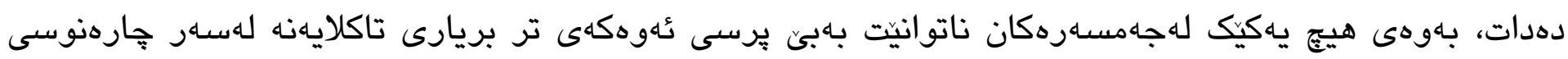

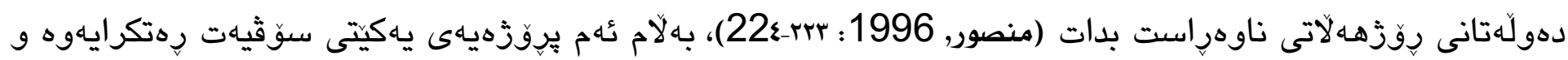

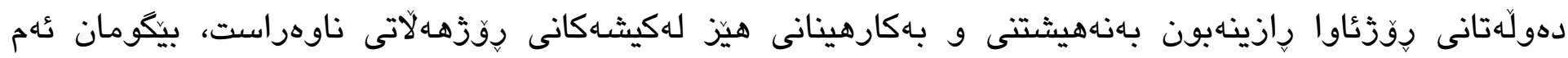

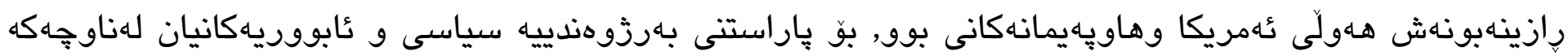
و ريّكريكردن لههـاهونى هـارهيَزيَكى تر لهم ناوجهيه (خضير, 2014: 418).

كاتيكيش كه كوّونهوهى ئهريكا و بهريتانيا لهدوركهى (بهرموده) له (ئادارى 190V) بهستراوكفتوكُّى بابهته

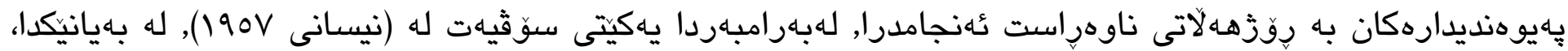
دزايهتى تئم كؤونهوهى راكهياند و تكهريكا و بهريتانياو فهرهنساى تومهاتباركرد, بهادوباره زيندوكردنهوهى

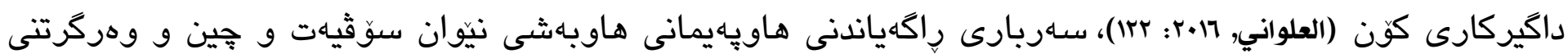

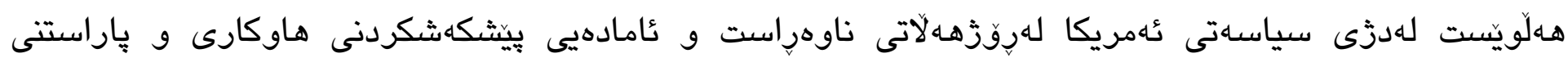

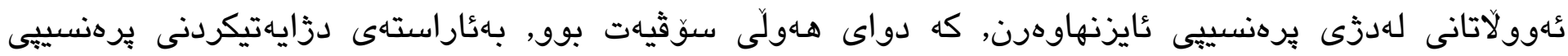

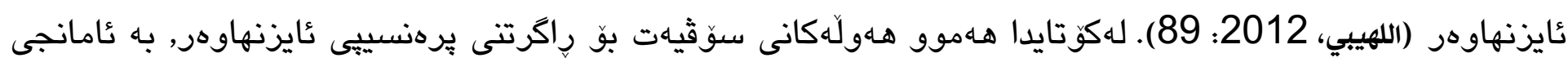

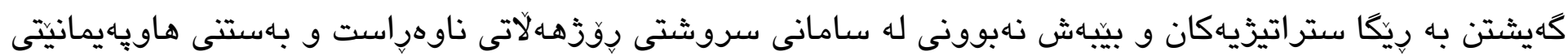
له لهَّل ولآتانى ناوجهـكه بوو. 


\section{ألهنجام}

له كوتايى نووسينى ئه تويَزْينهوهيهادا كَهيشتين بهم ئهنجامانهى خوارهوه:

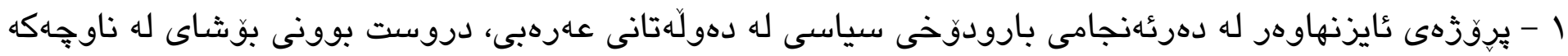

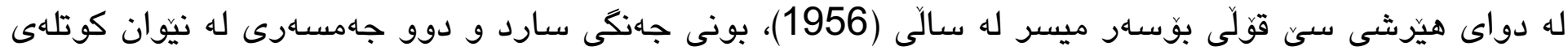

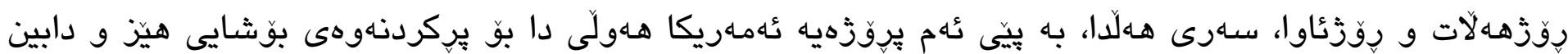

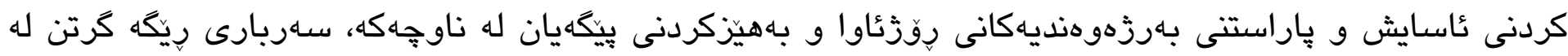

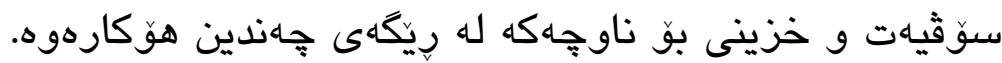

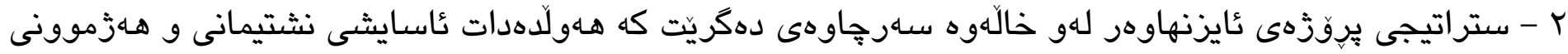

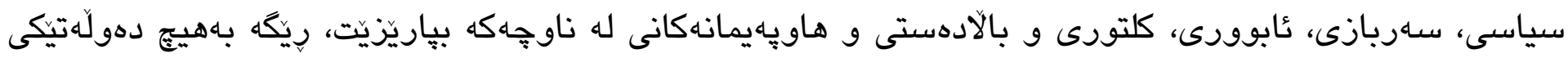

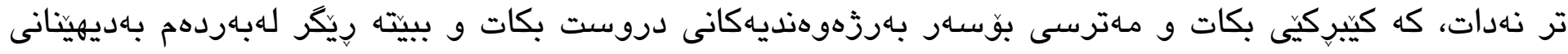

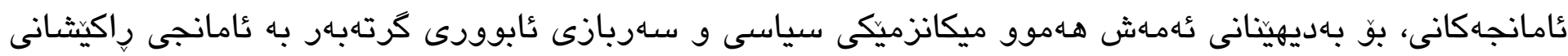

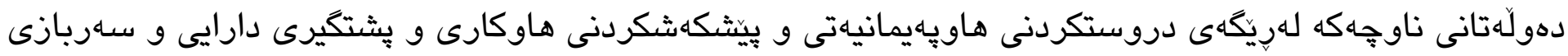
كه كُهماش كُورِانكارى تهواوى له ناوجهـكها هينايه كايهوه.

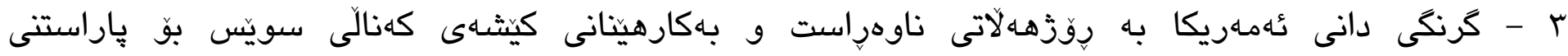

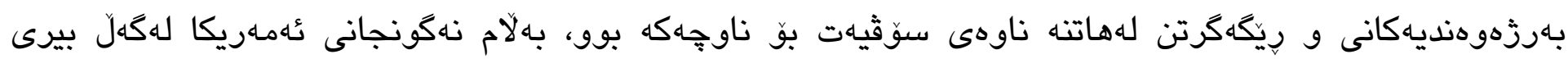

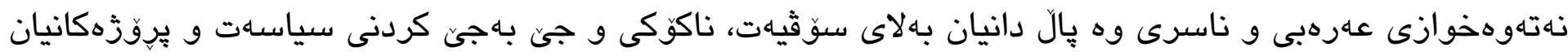

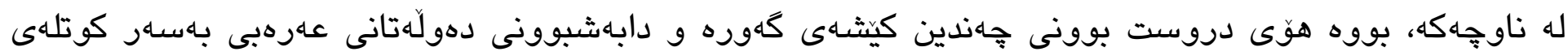

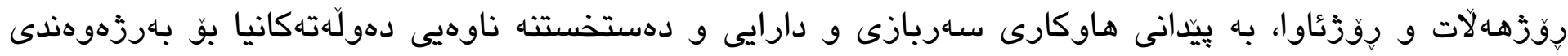

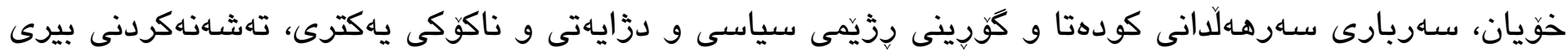

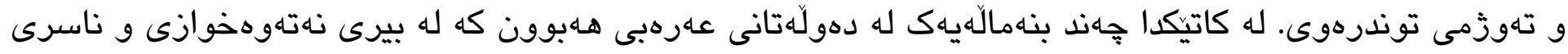

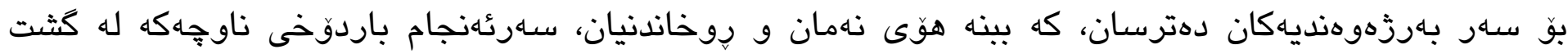

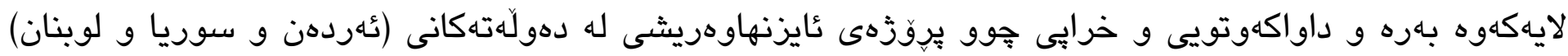

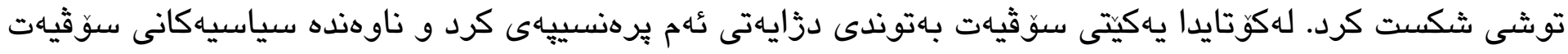

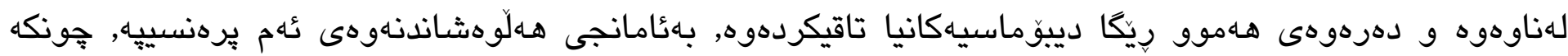

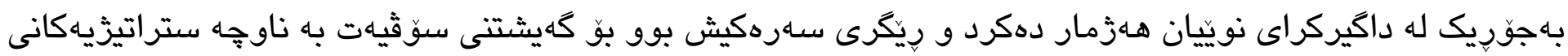
بروّْهلاتى ناوهراست. 


\title{
The Eisenhawer Doctrine (1957): The impact on Arabic Countries and The Soviet Union Attitude
}

\section{Harem Hasan Ahmad}

Department of History, College of Humanities, University of Raparin, Rania, Kurdistan Region, Iraq.

E-mail: haremranya58@uor.edu.krd

\section{Ribwar Khalid Mustafa}

Department of History, College of Humanities, University of Raparin, Rania, Kurdistan Region, Iraq.

E-mail: krebwar@uor.edu.krd

\section{Ibrahim Ali Salim}

Department of History, College of Humanities, University of Raparin, Rania, Kurdistan Region, Iraq.

E-mail: ibrahimali@uor.edu.krd

\begin{abstract}
:
Following the end of World War II, and emerging of a vacuum after the withdrawal of British and French forces from some of the Middle East countries in the region, creating fear in Western countries, particularly the United States, that the Eastern Bloc, in particular Russia, would seek to fill the vacuum and spread the idea of leftism and communism in the region. For this reason, the United States has made every effort to confront the idea of communism and establish a foothold in the region among its policies. To this end, then US President Harry Truman announced his country's new policy in the context of the Truman project on the Middle East in (1945). Following Harry Truman, when Eisenhower assumed power as the new US president in (1953), he put forward the new policy of his country named Eisenhower's Dwight in Congress in order to confront Russian politics and infiltrate communist thought in the area. There were several items in his project that
\end{abstract}


emphasized the cooperation of Middle Eastern countries, especially in the economic and military fields.

The Eisenhower's Dwight has had a variety of reactions from countries in the region, especially Arab countries. Some have accepted it from the very beginning. Some also expressed opposition to the project. There were also countries that initially opposed the Eisenhower project, but after a period of time following US efforts and pressure, eventually endorsed the project and became a fan of the US. As a result of these political divisions in the region, several political and military alliances between the countries of the Middle East Were formed. The idea of Nasser and the idea of Arab nationalism come to life at this time. Although originally favored by the Eastern Bloc, especially Russia, it also partially weakened the notion of communism and was about to cause tension between proponents of these two ideas. This situation had nothing in fact to do other than destabilizing the political state and the occurrence of several coups in order to change the regime of some of Middle Eastern countries, besides the long sovereignty of some Arab rulers.Regarding the Soveit Union attitude towards the Eisenhower's doctrine, it can be seen that,the Soveit Union ctitisized by the Soviet authorities from internal and external the SoveitUnbion.For instance the The Soveit Union attempted to gain extermal allies among the Middle Middle Eastren countries to convince them this doctrine is a part previous imperliams that supported by Westren countries.Finally,in the United Nation, The Soveit attempted to make a campaign to remove this doctrine as it mention a therat of world peace.

KeyWords: Middle East, Eisenhower, Arabic Countries, The Soviet Union Attitude. 


\section{سلورجاودكان}

ئهمهد، سامان حوسين، 2012، زلهيّزهكان، جֶايخانهى موكريانى، هـوليّر.

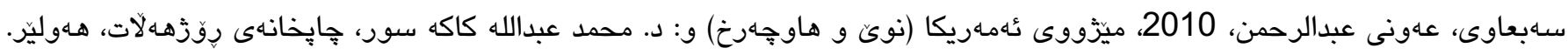

لاوهند، رهمهزان، 2007، جهنكى جيهانى دووهم، و: سهفين لاوجاك، جإخانهى جِوارجرا، سليمانى.

البيضانى، ابر اهيم سعيد، 2003، ابحاث في السياسة الامريكية تجاه المشرق العربى بعد الحرب العالمية الثانية، مركز الدراسات الاستر اتيجية، بغداد.

السبعاوي، فهر عباس، 2013، العلاقات السورية الامريكية (1949 - 1958)، دار غيداء للنشر و التوزيع، دمشق. الضيفي، ميثاق بيات، 2011، السياسة الامريكية تجاه إسر ائيل في إدارة الرئيس دوايت إيزنهاور ( 1953 - 1961)، دار غيداء للنشر و التوزيع، عمان. العدول، جاسم محمد حسين و آخرون، 1986، تأريخ الوطن العربي المعاصر، وزارة التعليم العالي و البحث العلمي، جامعة الموصل. العلو اني, ايدا طارق, 2016, سياسة الاتحاد السوفيتي الخارجية 1956 - 1964, دار سرمد للنشر, السليمانية. الككىى، يحيى احمد،1986، الثرق الاوسطو الصراع الدولي، دار النهضة العربية، بيروت. الكيالي، عبدالوهاب، 1974، الموسوعة السياسية، المؤسسة العربية للدر اسات و النشر، بيروت. النعيمي، احمد نورى، 1970، السياسة الخارجية التركية بعد الحرب العالمية الثانية، دار الحرية للطباعة، بغداد. ايزنهاور، دو ايت، 1965، مذكر ات ايزنهاور، ترجمة: هيوبرت يو نعمان، دار احيا التراث العربي، بيروت. بدون المولف, 1977, الاتحاد السوفيتى والثرق الاوسط مشاكل السلام و الامن 1956-1971, دار التقدم, موسكو. بريسون، توماس، 1985، العلاقات الديلوماسية الامريكية مع الثرق الاوسط (1784 - 1975)، دار طلاس للار اسات، دمشق. 
ر اثميل، أندرو، 1997، الحرب الخفية في الثرق الآوسط (1949 - 1961)، ترجمة: عبد الكريم محفوض، دار سلمية للكتاب، بدون مكان الطبع.

زور غبيب، شارل، 1978، سياسة الكبار في البحر الابيض المتوسط، ترجمة: خضر خضر ، توزيع جروس - برس، بيروت.

عبداللهيبي, اديب صالح, 2012, العلاقات السورية - السوفيتية 1946- 1964, دار الغيدان للنشر والتوزيع, عمان. عبدالله، إيناس سعدي، 2010، السياسة الامريكية ودور ها في مواجهة الدد الثيو عي في أوروبا (1945-1950)، أثوربانيبال للكتاب، بغداد. قرني، بهجت و حمودة، عبدالعزيز، 2004، صناعة الكر اهية في العلاقات العربية الامريكية، ط2 ، مركز دراسات الوحدة العربية، بيروت. كالرك و آخرون، رامز، 2001، الامبراطورية الامريكية، الجزء الآول، مكتبة الثروق، القاهرة. مجموعة المؤلفين, 1992, النار و الجليد الامبر اطورية الحمر اء من المهذ الى اللحد 1917- 1992, دار الحسام, بيروت. محافظة، علي، 2011، بريطانيا والوحدة العربية ( 1945 - 2005)، مركز در اسات الوحدة العربية، بيروت. مقلد، اسماعيل صبري، 1985، الاستر اتيجية و السياسة الدولية، مؤسسة الابحاث العربية، بيروت.

مقلد، اسماعيل صبري، 1986، الصراع الامريكي ـ السوفيتي حول الشرق الاوسط، منشورات ذات السلاسل، الكويت.

منصور، ممدوح محمود، 1996، الصر اع الامريكي - السوفيتي في الثرق الاوسط، مكتبة مدبولي، قاهيرة.

نعمان الدوري، اسامة عبدالرحمن، 2003، زيارة الملك الحسين بن طلال الى الولايات المتحدة الامريكية عام 1959 صلفحة جديدة من العلاقات الاردنية ـ

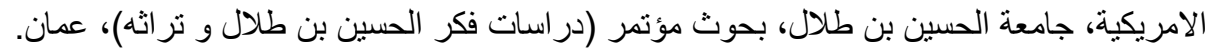

بن الصادق، جمال، 2017، الدور السوفياتي في الثرق الأوسط ما بين الفترة (1945 - 1991)، رسالة الماجستير، قدم ألى مجلس كلية العلوم الإنسانية و

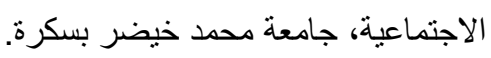

ذيب مليحة، نبيلة محمود، 2012، السياسة الامريكية تجاه ايران (1945- 1981)، رسالة الماجستير، قدم ألى مجلس كلية الآداب، جامعة الإسلامية، غزة. مخيير، شيماء فاضل, 2005, العلاقات السورية ـ السوفيتية 1946-1961, اطرحة دكتور الغير منشورة، جامعة بغداد, بغداد.

خضير , كريم حيدر, 2011, موقف العر اق من التنخلات الدولية 1956-1958, مجلة الاستاذ، مجلد الاول, عدد 210, بغداد. رديف طالب، محمد عماد، 2011، أثر مبدأ أيزنهاور على العلاقات السورية الآردنية (1957 - 1976)، مجلة (أداب الفراهيدي)، العدد (8). صلو اتى، ياسين، 2001، مؤسسة التاريخ العربي، الموسوعة العربية الميسرة و الموسعة، الجزء الخامس، بيروت. عبدالعال، سيد محمد، 2003، الموقف السوفياتي من مشروع إيزنهاور (1957 - 1958)، مجلة (كلية الأداب)، عدد (13). 
Laqueur, W., 1970. the Struggle for the Middle East: the Soviet union and the Middle East 1958 - 1968 London.

Olson, M., 2016. Dwight D. Eisenhower and the Suez Crisis of 1956, BA in history, he will begin work on an MA in history at the University of Missouri.

Reeves, T C., 2000. Twentieth-Century America, A brief history, NewYork.

Seale, P., 1966. The Struggle for Syria: A study of post war Arab politics, (1945 - 1958), Oxford.

Smit, LB., 1971. Responses to The Eisenhower Doctrine in The Middle East: An Analysis of a Status quo Policy, Submitted to the Faculty of the Graduate College of the Oklahoma State University in partial fulfillment of the requirements for the Degree of Master of Arts. 